\title{
Register of New Fruit and Nut Varieties Brooks and Olmo
}

\author{
List 37 \\ Edited by James N. Cummins \\ Department of Horticultural Sciences, New York State Agricultural Experiment Station, \\ Cornell University, Geneva, NY 14456
}

\author{
ALMOND \\ Dale E. Kester \\ Department of Pomology, University of California, Davis
}

Alenik.- Bred by A. Yadrov, N. Popov, and A. Rhikter at State Nikitski Botanical Gardens, Yalta, Crimea, Ukraine. Parentage: Texas × (Prunus dulcis 128/2 × Amygdalus bucharica 2714). Introd. in 1988. Nut: size medium to small; soft-shelled with average shelling percentage of $55 \%$; outer shell sparsely pored. Kernel: size intermediate; ovalshaped; color intermediate; flavor sweet; $\approx 15 \%$ double kernels. Maturity is early (mid-August). Bloom time late to very late (10 to $17 \mathrm{Apr}$.). Pollen cross-compatible with Nikitskyi 62 and Nikitskyi 2240. Tree: medium size; branching intermediate. Precocity similar to Nonpareil. Flower buds have high heat requirement but are extremely resistant to winter cold. Some resistance to Rhizopus stolonifera and Monilinia spp.

Fores.- Bred by A. Yadrov, N. Popov, and A. Rhikter at State Nikitski Botanical Gardens, Yalta, Crimea, Ukraine. Hatf-159 $\times$ Takida badem. Introd. in 1990. Nut: size large; shell semi-hard with $47 \%$ shell; outer surface sparsely pored. Kernel: large; ovate; intermediate color intensity; wrinkling intermediate; flavor sweet. Low tendency to doubles. Nut maturity early (mid-August). Bloom time very late. Pollen cross-compatible with Nikitskyi 62 and Desertyi. Flower buds have very high heat requirement and high resistance to winter cold. Tree: medium in shape and size; tends toward sparse branching and precocious bearing; some tendency forbiennial bearing. Reported to have resistance to Rhizopus stolonifera and high resistance to Monilinia.

Francoli.- Bred by F.J. Vargas Garcia and M.A. Romero Romero, Centre de Mas Bove, IRTA, Reus (Tarragona), Spain. Cristomorto $\times$ Gabaix. Cross made in 1976; introd. in 1992. Nut: very hard shell; shelling percentage $\approx 30 \%$. Kernel: large; semi-elliptical and pointed; few double kernels; slightly wrinkled; light brown pellicle of medium thickness. Bloom very late. Self-incompatible; pollinates Glorietta and Ferragnes. Maturity is early, late August. Tree: medium to strong vigor; medium upright; branching medium-sparse; foliage dense; easy to prune. Precocious; spur-bearer; very high production.

Glorietta.- Bred by F.J. Vargas Garcia and M.A. Romero Romero, Centre de Mas Bove, IRTA, Reus (Tarragona), Spain. Primorsky $\times$ Cristomorto. Cross made in 1975; introd. in 1992. Nut: large; very hard-shelled; shelling percentage slightly $>30 \%$. Kernel: large, elliptical, and pointed; few double kernels; pellicle smooth, light brown. medium thick; high quality. Maturity medium late, early September. Bloom: late to very late. Self-incompatible; cross-fertile with Masbovera, Francoli, and Ferragnes. Tree: strong vigor; upright; slightly open structure; dense foliage; very easy to train and prune. Bears primarily on spurs; precocious. Easy to harvest and hull.

Heleodor.- Bred by A. Yadrov, N. Popov, and A. Rhikter at State Nikitski Botanical Gardens, Yalta, Crimea, Ukraine. Nitikskyi $62 \times$ IXL. Introd. in 1988. Nut: size small, similar to Texas: shell light, soft, and easily broken by hand; shelling percentage $\approx 55 \%$; outer shell densely pored. Kernel: small (like Texas); oval; sweet; slight wrinkling; color intensity intermediate; low tendency to double. Nut matures early (with Nonpareil). Bloom late to very late; cross-compatible with Desertnyi and Nitikskyi 2240. Heat requirement for flower bud emergence very high (like Primorski). Tree: medium size; tends to be precocious, bearing on 4- to 5-year-old tree; some tendency for biennial bearing. Extremely resistant to winter cold. Shows resistance to Rhizopus stolonifera and Monilinia spp.

Lauranne.- Bred by Charles Grasselly, INRA. Avignon, France. Ferragnes $\times$ Tuono. Introd. in 1989. Shell: hard; shelling percentage $\approx 38 \%$; smooth surface. Kernel tends to be small and ovate; slightly wrinkled; color light; tendency to double (5\% to $15 \%$ ). Maturity medium early (mid-September). Bloom late to very late. Tree: spreading to drooping; medium vigor; precocious.

Mangup.- Bred by A. Yadrov, N. Popov, and A. Rhikter at State Nikitski Botanical Gardens, Yalta, Crimea, Ukraine. Nonpareil x (Nikitskyi $62 \times$ Nikitskyi 53). Introd. in 1989. Nut: large (like Ne Plus Ultra); shell semi-hard with shelling percentage of $49 \%$ (like Texas); surface sparsely pored. Kernel: size large (like Ne Plus Ultra); ovate; slightly bitter taste (like Texas): wrinkling intermediate; color intensity intermediate; some tendency to wrinkle; low doubling percentage. Matures early (with Nonpareil). Bloom late (with Texas). Pollen cross-compatible with Desertnyi, Nikitskyi 2240. Heat requirement of flower buds very high (like Primorski). Flower buds very resistant to winter cold. Tree: medium size and shape; branching intermediate; some tendency to biennial bearing. Resistant to Rhizopus stolonifera and very high resistance to Monilinia spp.

Masbovera.- Bred by F.J. Vargas Garcia and M.A. Romero Romero, Centre de Mas Bove, IRTA, Reus (Tarragona), Spain. Primorski $\times$ Cristomorto. Cross made in 1975; introd. in 1992. Nut: very hard shell; shelling percentage $\approx 30 \%$ or slightly less. Kernel: size medium to large; few doubles; elliptic and pointed; pellicle smooth, light brown, medium thick; quality high. Matures medium-late (early September). Bloom late to very late. Self-incompatible; pollinators include Glorietta, Francoli, and Ferragnes. Tree: vigorous; medium upright; dense foliage. Precocious; very productive; strong spurbearer.

Rhikter.- Bred by A. Yadrov, N. Popov, and A. Rhikter at State Nikitski Botanical Gardens, Yalta, Crimea, Ukraine. (A. dulcis $1281 / 2 \times$ A. bucharica) $\times$ Vinoslivyi. Introd. in 1984. Nut: medium size; medium shell color; semi-soft; $52 \%$ shell; surface densely pored. Kernel: size medium; oval; slight wrinkling; color intermediate. High tendency to double (25\%). Maturity date medium (like Ne Plus Ultra). Bloom very late (10 to $18 \mathrm{Apr}$.). Flower buds have very high heat requirement. Pollen cross-compatible with Nikitskyi 62 and Desertnyi. Tree: medium shape; medium size; branching dense (like Marcona); precocious. Flower buds very resistant to winter cold. Tends to have thin shoots.

Steliette.- Orig. by Chas. Grasselly, INRA, Avignon, France. Ferragnes $\times$ Tuono. Introd. in 1989. Shell: semi-hard with a shelling percentage $\approx 45 \%$; outer surface smooth. Kernel: size large; ovate; moderately wrinkled; light color. Some double kernels, ranging from $5 \%$ to $10 \%$. Early maturing. Bloom late to very late; self-compatible. Tends toward early bearing. Tree: medium vigor; somewhat difficult to train.

\section{ALMOND ROOTSTOCKS}

Adarcias.- Described under peach rootstocks. Compatible with most commercial almond varieties. 


\section{APPLE}

Roger D. Way and Susan K. Brown

New York State Agricultural Experiment Station, Geneva

Ambassy $^{\mathrm{TM}}$ - - Red sport of Delcorf, introd. by DavodeauLigonniere Nursery, Angers, France. Fruit: striped red-orange; flavor acid; ripens 2 weeks before Gala; 2-month storage life at $-0.5 \mathrm{C}$.

Ambrosia.- A good quality red apple ripening in Delicious season. Chance seedling discovered in early 1980s by Wilfred and Robert Mennell, Cawston, B.C. U.S. and Canadian plant patents applied for; assigned to Okanagan Plant Improvement Co. Fruit: good size; very attractive; crisp; sweet, low acid; very juicy; distinct, pleasant aroma. Tree: grower-friendly; productive.

Daliter.- Synonym for Elton.

Delcorf.- Bred and introd. by Georges Delbard Nursery, Malicome, France. Golden Delicious $\times$ Stark JonGrimes. Fruit: size medium to medium-large; skin very smooth with few lenticels, half covered with bright red stripes over bright yellow ground; shape upright cylindrical; flesh yellow, crisp, juicy; aromatic; slightly astringent; fruits firm, not subject to bruising. Harvest in late August, 2 weeks before Gala; sensitive to premature fruit drop. Storage life 1 month; does not become mealy. Tree: medium vigor: branches split off easily in young trees; productive, some tendency to biennial bearing. Sets fruit on 1year-old wood.

Delkistar.- Synonym for Regali ${ }^{\circledR}$

Elton (Daliter).- A red-fruited sport of Elstar, discovered by M. Peter, Loire Atlantique, France. Fruit: bright red-orange, striped. Otherwise fruit and tree are identical with Elstar. Heavily planted in France.

Regali ${ }^{\circledR}$ (Delkistar).- Orig. at Malicorne, France, in the breeding program of Georges Delbard Nursery. Kidd's $28 \times$ Starkrimson Delicious. Fruit: size large, 75 to $8.5 \mathrm{~mm}$, more than $200 \mathrm{~g}$; truncated cone; skin red, striped on yellow-green ground color; very firm; very good eating quality; well suited for processing. Harvest 10 days after Gala; requires two or three pickings. Tree: vigorous; uprightspreading; productive. Blossoms with Golden Delicious; pollinated by Golden Delicious, Delicious, Granny Smith, Gala, and Golden Gem.

\section{APPLE ROOTSTOCKS}

\section{J.N. Cummins}

New York State Agricultural Experiment Station, Geneva

Geneva 11 (G.11).- A disease-resistant rootstock introd. in 1993 by J.N. Cummins and H.S. Aldwinckle, New York State Agr. Expt. Sta., Geneva. Malling $26 \times$ Robusta 5; cross made in 1978; tested as 7826R5-011 and as CG.11. Plant patent applied for by Cornell Research Foundation; being propagated by licensed nurseries. Tolerant to Phytophthora cactorum; moderately resistant to fire blight, including virulent strain Ea 266; susceptible to woolly apple aphids and powdery mildew. Trees on G.11 are well-anchored, precocious, and productive; few burrknots and suckers; moderate number of short spines on liners. Readily propagated in layerbeds and by cuttings. Spring budbreak late, like M.26.

G.11.- Diminutive for Geneva 11 .

\section{ASIAN PEARS (NASHI)}

Joseph D. Postman and Kim E. Hummer

\section{U.S. Department of Agriculture National Clonal Repository,} Corvallis, Ore.

Daisui Li.- A large, smooth-skinned, pyriform Asian pear orig. at Univ. of California, Davis. Kikusui $\times$ Tse Li (Tsu Li); tested as selection 12-44 near Winters, Calif. Introd. by Ben Iwakiri in 1988. Plant patent 6075 , Jan. 1988. Fruit: large to very large; obovate to globular, more pear-shaped than most Asian pears; skin smooth, thick, light green; flesh white, firm, coarse, crisp, juicy, sweet, subacid; distinct aroma, similar to Tse Li. Ripens in early September in Davis. Fruit stores 5 to 6 months at 0C. Tree: large; more vigorous than other Asian varieties; upright to slightly spreading; open; hardy. Blooms with Chojuro and Kikusui, before Bartlett, slightly after Ya Li and Tse Li. Resistant to fire blight.

Gold Nijisseiki.- A mutation of Nijisseiki resistant to black spot disease. Developed at the Inst. of Radiation Breeding at the National Inst. of Agrobiological Resources, Ohmiya-machi, Ibaraki, Japan, from gamma-irradiated buds of Nijisseiki. Registered as Pear Norin 15; named and released in 1991 by T. Sanada, K. Kotubuki, T. Nishida, H. Fujita, and F. Ikeda. Similar in habit, flowering season. and fruit characteristics to Nijisseiki, except fruit ripens a few days later and tree is resistant to the Japanese pear pathotype ofAlternaria alternata: not as resistant as Chojuro.

Shin Li.- A fine-textured, fire-blight-resistant Asian pear bred at Univ. of California, Davis. A cross between the Japanese pear, Kikusui, and the Chinese variety. Tse Li (Tsu Li); tested near Winters, Calif. as selection 12-43. Plant patent 6076, Jan. 1988; introd. by Ben Iwakiri in 1988. Fruit: medium to large; round-oblate, slightly flatter than Daisui Li. Skin thick, smooth, light green to yellow-green: flesh firm, tender, crisp, juicy, sweet: texture finer than Daisui Li. Ripens early September at Davis; stores 5 to 6 months at 0C. Tree: vigorous; large to medium; upright to slightly spreading. open; hardy; resistant to fire blight. Leaves large, wide, leathery. Blooms early, with Chojuro, slightly after $\mathrm{Ya} \mathrm{Li}$ and $\mathrm{Tse} \mathrm{Li}$.

Shinsui.- A russetted, early-midseason Japanese pear selected in 1956 at Yatabe, Japan. Kikusui $\times$ Kimizukawase. Introd.in 1967 by M. Kajiura, K. Kanato, Y. Machida. and I. Kozaki at the Horticultural Research Station, Yatabe. Fruit: medium size, 250 g; skin yellowbrown, russetted; globose-oblate; flesh crisp, juicy, fine texture, very sweet; not as firm as other Asian pears; excellent eating quality. Ripens mid-August in Oregon and Washington. Susceptible to black spot (Alternaria). A superior replacement for Ishiiwase.

\section{BLACKBERRIES AND HYBRID BERRIES}

Hugh Daubeny

Pacific Agriculture Research Centre, Vancouver, B.C.

Adrienne.- An early-ripening, genetically spineless trailing blackberry with excellent fruit quality. Orig. in Kent, England, by D.L. Jennings, Medway Fruits. Silvan x unnamed seedling; introd. in 1995. Worldwide marketing rights held by NSA Plants, West Mailing, Kent. Fruit: size between 6.0 and $6.5 \mathrm{~g}$, similar to Silvan: firm, long, conic; attractive, bright, regular appearance; ripens early July in southern England, 1 week after Silvan and 1 week before Waldo; excellent flavor; better adapted to distant markets than Silvan. Plant: high yield potential; first-year canes stout, spine-free, vigorous, and spreading; second-year canes short, stout, good fruit exposure.

Arapaho.- An early-ripening, genetically spineless, erect blackberry with excellent fruit quality. Orig. in Fayetteville, Ark., by J.N. Moore and J.R. Clark, Dept. of Horticulture, Univ. of Arkansas. Ark. $631 \times$ Ark. 883. (Both parents are heterozygous for recessive spineless genes derived from Merton Thornless via Thornfree). Cross made in 1982; selected in 1985; tested as Ark. 1536; introd. in 1993. Plant patent applied for. Fruit: medium size; bright glossy black; firm; small seed size; short conic shape; earlier ripening than any other spineless blackberry cultivars; concentrated season of 4 weeks; high soluble solids concentration; stores well; excellent flavor fresh and processed. Plant: productivity probably similar to Navaho; moderately vigorous; very erect spineless canes; produces more primocanes from roots than Navaho; good cold hardiness to $-24 \mathrm{C}$. No symptoms of either orange rust or rosette have been observed despite high levels of inoculum of the respective causal organisms.

Douglass.- A high-yielding, genetically spineless trailing blackberry with excellent fruit quality. Orig. in Hillsboro, Ore., by B.S. Douglass. Lawrence $\times$ Sander (both derived from Boysenberry and several ORUS blackberry selections; Sander also derived from Austin Thornless, Chehalem, Marion, and Lincoln). Cross made in 1984; selected in 1986; introd. in 1993. U.S. plant patent 8423, Oct. 1993. Fruit: medium to large size; medium-large drupelets with small seeds; glossy black; medium firm, similar to Marion; skin medium tender; bluntly conic to bluntly pointed cylindrical; midseason ripening; easy to harvest; adapted to machine harvest: excellent flavor typical of 
Rubus ursinus derivatives; fresh and processing. Plant: vigorous trailing canes require trellis; small incipient spines tend to disappear as canes grow. Moderately resistant to leaf and cane spot.

Fertodi botermo.- A large-fruited trailing hybrid berry. Orig. at Fertod Research Station, Hungary, by L. Kollanyi and M. German. F seedling of Logan x (Rubus caesius x Lloyd George); selected in 1968; tested as F. 9086/21; introd. in 1980. Fruit: large; dark red; long shape; early ripening; acid flavor. Plant: very productive; moderately vigorous; trailing habit.

Fertodi Hungaria.- A large-fruited hybrid berry with a mild, sweet flavor suitable for fresh market. Orig. at Fertod Research Station, Hungary, by A. Porpaczy and L. Kollanyi. $\mathrm{F}_{2}$ seedling of Logan x (Rubus caesius x Lloyd George); selected in 1963; tested as F. 9001/1 88; introd. in 1965 . Fruit: light red; early ripening. Plant: very tall.

Kaiteri.- A hybrid berry with high acid content, suited for processing. Orig. in Nelson, New Zealand, by H. Hall, Riwaka Research Centre. SCRI 78154E3 x SCRI 79102E8; cross made in 1982 by D.L. Jennings, Scottish Crop Research Inst.; selected in New Zealand in 1985; tested as 8242B68; introd. in 1991. Fruit: medium size; wine red color; very soft, especially when overripe; strong flavor; ripens as much as 6 days before Boysenberry. Plant: moderate numbers of medium-strength spiny canes.

Mahana.- A large-fruited, trailing hybrid berry suited to pickyour-own operations. Orig. in Nelson, New Zealand, by H. Hall, Riwaka Research Center. Aurora x Loganberry; cross made in 1981; selected in 1983; tested as 815M167; introd. in 1990. Fruit: very large; wine red to dark red when fully ripe; especially soft at high temperatures; ripens 1 week before Boysenberry; strong flavor. Plant: very high-yielding; many fruits per lateral; numerous strong and spiny canes.

Mapua.- A spineless Boysenberry mutation. Orig. in Nelson, New Zealand, by H. Hall, Riwaka Research Center, in the Boysenberry Clonal Reselection Program; introd. in 1994. Fruit: similar to Boysenberry; easy to harvest; adapted to machine harvest. Plant: highyielding; easily managed canes.

Murrindindi.- A spineless, trailing blackberry with good fruit quality. Orig. in Toolangi, Australia, by G. McGregor, Inst. for Horticultural Development, Victoria. Silvan x a thornless blackberry hybrid of complex origin; cross made by D.L Jennings, Scottish Crop Research Inst.; selected at Toolangi; tested as A85-15-A3; introd. in 1994. Fruit: similar to Silvan but slightly smaller with smaller drupelets; ripens after Silvan and before Smoothstem. Plant: canes shorter than Silvan with shorter internodes; spineless.

Ranui.- A hybrid berry producing high-quality fruit for freshmarket use. Orig. in Nelson, New Zealand, by H. Hall, Riwaka Research Center. Aurora x Marion; cross made in 1983; selected in 1985; tested as 833158; introd. in 1990. Fruit: medium size; medium to dark red, firm; small drupelets; longer and thinner shape than Boysenberry; ripens 2 to 3 weeks before Boysenberry; when harvested before complete ripeness, it retains pleasant, mild flavor. Plant: many medium-strength canes; good budbreak; even lateral development.

Riwaka Tahi.- A firm-fruited hybrid berry with Boysenberrylike flavor. Orig. in Nelson, New Zealand, by H. Hall, Riwaka Research Center. Aurora x Boysenberry; cross made in 1983; selected in 1985; tested as 832F74; introd. in 1990. Fruit: medium size; winered color; firm; many tightly packed drupelets; moderate force required to separate from calyx; ripens up to 2 weeks before Boysenberry; fresh market. Plant: lower yield than Boysenberry; fruit numbers per lateral similar to Boysenberry; medium-strength, spiny canes; good budbreak, but may show uneven lateral development.

Taranaki.- A firm-fruited hybrid berry with typical blackberrylike flavor for fresh market. Orig. in Nelson, New Zealand, by H. Hall, Riwaka Research Center. Aurora x Cherokee; cross made in 1982; selectedin 1985; tested as 821C93; introd. in 1990. Fruit: medium size; turns dark black about 1 week before fully ripe, difficult to distinguish when fully ripe; very firm; many tightly packed drupelets; ripens up to 2 weeks before Boysenberry. Plant: lower yield than Boysenberry; moderate numbers of spiny canes of medium strength; foliage often shows genetic chlorosis.

Tasman.- A spineless Boysenberry mutation. Orig. in Nelson,
New Zealand, by H. Hall, Riwaka Research Center. in the Boysenberry Clonal Reselection Program; introd. in 1994. Fruit: size, shape, and color intermediate between Boysenberry and Youngberry; extends Boysenberry harvest season. Plant: high-yielding; initial slow establishment.

\section{GRAPES}

John R. Clark

University of Arkansas, Fayetteville

Aki Queen.- Large-fruited, seeded table grape. Orig. in Akitsu, Hiroshima, Japan, by Hiroyasu Yamane. Kyohou selfed. Introd. in 1991. Berry: very large (13 g); obovate; bright red; treatment with gibberellic acid can improve fruit set and induce seedlessness; foxy flavor. Cluster: winged-conical; loose. Vine: vigorous; downy and powdery mildew resistance higher than $V$. vinifera cultivars.

Aki Seedless.- Seedless black table grape. Orig. in Akitsu, Hiroshima, Japan, by Hiroyasu Yamane. Muscat Bailey A x Himrod; selected in 1972; tested as Akitsu-1; introd. in 1986. Berry: medium (3 g); short-elliptic; slipskin; no aroma. Cluster: large; winged-conical; well-filled. Vine: fairly vigorous; productive; moderately resistant to ripe rot and downy mildew; cold hardiness is low.

American Rose.- Large, very firm, seeded table grape. Orig. in Fowler, Calif., by John Paboojian, Jr. Plant patent 6829, 6 June 1989. Chance seedling of unknown parentage. Berry: variable color, depending on season and culture; but under favorable conditions, has a dominant color of reddish-brown with a small, greenish-white halo encircling the pedicel; large (9.2 g); neutral flavor; three seeds/berry. Cluster: medium; loose but well-filled; conical. Vine: vigorous; productive; one or two clusters/shoot. Released as an extremely firm, large, fresh-market grape.

Belair.- Orig. in Roodeplat, Republic of South Africa, by E.P. Evans and P.J.L. Ellis, Viticultural and Oenological Research Inst. Barlinka x Black Spanish; tested as 74-1407; introd. in 1986. Berry: large $(8 \mathrm{~g})$; oblate; blue-black; firm; not juicy; neutral flavor. Cluster: large; oblong; well-filled and compact. Vine: vigorous; basal buds fruitful; productive. Released as a table grape with good storage potential that ripens in mid- to late-season.

Bellevue.- Seeded white table grape. Orig. in Stellenbosch, Republic of South Africa, by P.J.L. Ellis and E.P. Evans, Viticultural and Oenological Research Inst. Olivette Blanche open-pollinated; tested as C2- 17; introd. in 1982. Berry: large (9 g); round-oval. Cluster: large; more round than oblong; uniform. Vine: productive; vigorous. Developed as a replacement for Waltham Cross.

Bianco One.- Synonym for Queen Arlene ${ }^{\mathrm{TM}}$.

Black Emerald.- Black, seedless grape for fresh market. Orig. in Fresno, Calif., by David W. Ramming and Ronald Tarailo. Not patented. A69-190 x C84-116; selected in 1987; tested as A12-137; introd. in 1994. Berry: round to slightly oval; medium size $(2.5 \mathrm{~g})$; responds to gibberellic acid at a rate lower than required for Thompson Seedless; flavor is sweet and neutral, best when harvested with at least $18 \%$ solids; two to four aborted seeds that are very small and undetectable. Cluster: medium in size and length; conical with a shoulder; wellfilled to slightly compact. Vine: medium vigor; production good to high when cane-pruned. Fruit ripens early, between Perlette and Flame Seedless. Recommended as an early ripening, fresh-market table grape.

Bonnoir.- Black, late-season, seeded table grape. Orig. in Stellenbosch, Republic of South Africa, by E.P. Evans and P.J.L. Ellis, Viticultural and Oenological Research Inst. Barlinka x Alphonse Lavallee; tested as 11-2-63; introd. in 1986. Berry: large (8 g); shortoval; firm; not juicy; neutral Flavor. Cluster: medium-large; oblong with well-developed shoulders; well-filled to slightly compact. Vine: vigorous; productive. Developed as a late-season, black, low-cracking variety.

Dauphine.- Late-season, white, seeded table grape. Orig. in Stellenbosch, Republic of South Africa, by P.J.L. Ellis and E.P. Evans, Viticultural and Oenological Research Inst. Almeria open-pollinated; tested as B 16-32; introd. in 1983. Berry: large (9 g); long; oval; firm; sweet-neutral flavor. Cluster: large; oblong; well-filled to slightly 
compact; shouldered. Vine: vigorous; productive; similar to other cultivars for disease susceptibility. Developed as a late-season, white, crack-resistant variety.

Fantasy Seedless.- Black, seedless grape for fresh market. Orig. in Fresno, Calif., by David W. Ramming and Ronald Tarailo. B36-27 x C78-68; selected in 1981; tested as C23-92; introd. in 1994. Not patented. Berry: mostly oval; large (6.5 g); firm; sweet flavor; one or two soft, small, aborted seeds/berry. Cluster: medium; mediumcompact to loose. Vine: vigorous; moderately productive when canepruned. Vines should not be sprayed with gibberellic acid due to resulting poor berry set, crop elimination the following year, and elongated vegetative growth. Fruit ripens slightly before Ribier. Recommended as a large-fruited, fresh-market grape.

Florida Fry.- Bronze, self-fertile muscadine. Orig. in Leesburg, Fla., by J.A. Mortensen, J.W. Harris, and D.L. Hopkins. Triumph x Fla. AD3-42; selected in 1987; tested as AA7-44. Not patented. Berry: spherical; large (9.9 g); 3.5 seeds/berry; firm pulp, which, along with edible skin, breaks up easily when chewed; $75 \%$ dry scars. Ripens over extended period. Cluster: moderately loose; 6.3 berries/cluster. Vine: less vigorous than Fry; vines can be spaced more closely than most muscadines: self-fertile. No Pierce's Disease observed; more resistant to ripe rot, bitter rot, and black rot than Fry, Triumph, and Summit.

Four Five.- White, mostly seedless table grape. Orig. in Fresno, Calif., by John M. Garabedian. Plant patent 5908, 17 Mar. 1987. Almeria x unknown male parent; selected in 1968. Berry: medium; two to four vestigial seeds/berry that are not noticeable when eaten; mostly oval and elongated; soft; juicy; sweet. Fruit ripens 2 weeks before Delight. Cluster: large and long; cylindrical; medium density; double-shouldered. Vine: medium vigor to vigorous; productive; one or two clusters/shoot. Primary use is for fresh market but also suitable for raisin production.

Gar Muscat.- White, seeded. table grape. Orig. in Fresno, Calif., by John M. Garabedian. Plant patent 5907, 17 Mar. 1987. Lebanese No. 9 x Gar-Supreme; selected in 1978. Berry: light yellow; oblate; medium-large (4.5 g); one to four seeds/berry; soft and crisp; juicy; sweet, subacid, and spicy flavor. Fruit ripens 10 to 14 days before Muscat of Alexandria. Cluster: medium to large; conical; well-filled. Vine: vigorous; productive. Developed as an improved Muscat of Alexandria-type variety with better cluster fill, crisper texture, and earlier ripening

Garlate.- White, late-ripening, seedless table grape for fresh market. Orig. in Fresno, Calif.. by John M. Garabedian. Plant patent 5987, 19 May 1987. Seedling of two vines selected from a population of seedlings from a Lebanese variety; selected in 1977. Berry: large (3 to $4 \mathrm{~g}$ ); oblate and cylindrical; soft and meaty; medium juicy; sweet. Ripens several days after Garmeria (10 to 15 Oct. at Fresno). Cluster: large to very large; long; broad and tapering; medium in density. Vine: vigorous; productive.

Honey Seedless.- Triploid. seedless table grape. Orig. in Akitsu, Hiroshima, Japan, by Hiroyasu Yamane. Kyohou x Concord Seedless; selected in 1976; introd. in 1993. Berry: greenish-yellow; round; small $(2 \mathrm{~g})$; responds to gibberellic acid treatment; slipskin; mild foxy flavor. Cluster: small to medium size; cylindrical and shouldered; loose. Vine: vigorous: more resistant to downy and powdery mildew than $V$. vinifera varieties; medium cold hardiness.

Jolly.-Seedless table grape. Orig. in San Rafael, Mendoza, Argentina, by Angel A. Gargiulo. Plant patent 8547, 18 Jan. 1994; assigned to Milan M. Caratan and Luis M. Caratan. A hybrid of Lattuario Nero, Cardinal, and Thompson Seedless (complete pedigree not available): selected in 1969. Berry: pink-red; good size; good flavor. Cluster: loose.

Kat.E.Lin.- Seeded, multiuse grape. Orig. in Smithville, Ont., Canada, by William L. Lounsbury, Sr., and Maurice W. Lounsbury. Plant patent 7644, 10 Sept. 1991. Mutation of Concord. Berry: red to dark-maroon; size medium (2.7 g); round to oblate; slipskin; mild foxy flavor; two or three seeds/berry; high sugar (19 to $22^{\circ}$ Brix). Cluster: small to medium; winged; conical; loose; three or four clusters/shoot. Vine: vigorous: productive; hardy to temperatures below $-18 \mathrm{C}$; resistant to mildew; fruit ripens $\approx 5$ days before Concord. Released as an earlier ripening, sweeter variety compared to Concord, for use as a fresh-market: jam; juice; or sweet, dessert wine grape.
King Husainy.- Seedless, white table grape. Orig. in Zichron, Ya'acov, Israel, by Mordechai Karniel. Plant patent 6464, 13 Dec. 1988; assigned to Zanzivivai-Ferrara S.r.1. V. vinifera parentage. Berry: very large ( $40 \mathrm{x} 18 \mathrm{~mm})$; green-yellow; very firm; crisp; neutral flavor; no seed traces. Cluster: medium; conical; very loose. Vine: vigorous; productive; fruit ripens 1 week after Superior Seedless, 2 weeks before Thompson Seedless.

La Rochelle.- Early-ripening, seeded table grape. Orig. in Stellenbosch, Republic of South Africa, by E.P. Evans and P.J.L. Ellis, Viticultural and Oenological Inst. Barlinka x Alphonse Lavallée; selected in 1979; tested as 11-13-96; introd. in 1986. Berry: large (9 g); blue-black; round; neutral flavor. Cluster: oblong; medium-large; well-filled to slightly compact. Vine: vigorous; productive; disease susceptibility similar to other cultivars. Developed as an early ripening, black variety with exceptional cold-storage capability.

Marroo Seedless.- Black, seedless table grape. Orig. in Merbein, Victoria, Australia, by Allan J. Antcliff, Commonwealth Scientific and Industrial Research Organization. Plant patent 7377, 6 Nov. 1990; assigned to CSIRO. Carolina Blackrose x Ruby Seedless; selected in 1978; tested as MS23-7. Berry: blue-black; medium-large (4.5 to 6.0 $\mathrm{g}$ without gibberellic acid application); short elliptic; firm; juicy; neutral flavor; occasional lignified rudimentary seed. Fruit ripens about 2 weeks before Ruby Seedless. Cluster: large; loose; uniform. Vine: vigor similar to Ruby Seedless. Released as a naturally largeberried, seedless table grape.

Micala.- Dark-red, seedless table grape. Orig. in Fowler, Calif., by Alan J. Asadoorian. Plant patent 6348, 25 Oct. 1988. Ribierx Black Beauty Seedless; selected in 1984. Berry: dark red with bluish hue; medium ( $3.8 \mathrm{~g}$ ); average of 1.5 seed traces per berry; oval; juicy; sweet flavor. Fruit ripens with Ribier. Cluster: medium to large; tapering, with one or two shoulders; well-filled. Vine: vigorous; productive; two or three clusters/shoot.

Muscat Seedless.- White, muscat-flavored table grape. Orig. in Stellenbosch, Republic of South Africa, by E.P. Evans and P.J.L. Ellis, Viticultural and Oenological Research Inst. Muscat of Alexandria $x$ Perlette: selected in 1982; testedas 12-16-102; introd. in 1986. Berry: yellowish-green; small (3 g); roundish; firm; juicy. Cluster: medium; slightly oblong; well-filled to slightly compact. Vine: vigorous; productive. Retains its flavor in storage.

North Black.- Black, seeded table grape. Orig. in Akitsu, Hiroshima, Japan, by Hiroyasu Yamane. Introd. in 1991. Seneca x Campbell's Early. Berry: medium (4 g); violet-black; round; slipskin; foxy flavor. Cluster: medium; moderately compact; winged-cylindrical. Vine: somewhat low vigor: hardiness similar to Campbell's Early; fairly resistant to diseases.

North Red.- Early ripening, hardy, seeded table grape. Orig. in Akitsu, Hiroshima, Japan, by Hiroyasu Yamane. Introd. in 1990. Seneca x Campbell's Early. Berry: medium (4 g); round; red-brown; slipskin; foxy flavor. Cluster: medium; moderately compact; wingedcylindrical. Vine: moderately vigorous; productive; hardiness similar to Campbell's Early; fairly resistant to diseases.

Pêrel.- White, muscat-flavored, early ripening, seeded table grape. Orig. in Stellenbosch, Republic of South Africa, by E.P. Evans and P.J.L. Ellis, Viticultural and Oenological Research Inst. Queen of the Vineyard x Jacaranda; selected in 1980; tested as 71-20; introd. in 1986. Berry; medium; round; yellow-green to straw-colored; soft; juicy; delicate muscat flavor. Cluster: small, conical; well-filled. Vine: moderate vigor; moderately productive; similar susceptibility to diseases as other varieties. The earliest ripening commercial variety in South Africa.

Queen Arlene $^{\mathrm{TM}}$ (Bianco One)- Red, seedless, early ripening table grape. Orig. in Mecca, Calif., by Robert O. Bianco. Plant patent 8463, 16 Nov. 1993; assigned to Anthony Vineyards. Mutation of Flame Seedless. Berry: small $(1 \mathrm{~g})$; gibberellic acid treatment increases size to $3 \mathrm{~g}$; oblate; slightly flat; neutral flavor; very crisp. Cluster: medium; compact; conical. Vine: medium vigor; productive. Fruit ripens $\approx 15$ days earlier and has smaller berries than Flame Seedless.

Rouge.- Red, seeded table grape, an early ripening sport of Emperor. Orig. in Delano, Calif., by George L Caratan. Plant patent 6421, 29 Nov. 1988; assigned to Anton George Caratan. Berry: large 
(9.9 g); two or three seeds/berry: oval or occasionally roundish; sweet and subacid flavor. Cluster: very large; long: conical; double-shouldered; well-filled but not compact. Vine: average vigor to vigorous; productive: one cluster/shoot; fruit ripens 2 to 3 weeks before Emperor.

Rubistar.- Dark red, early-ripening, seeded table grape. Orig. in Roodeplat, Republic of South Africa, by E.P. Evans and P.J.L. Ellis, Viticultural and Oenological Research Inst. Queen of the Vineyard $\mathrm{x}$ Muscat Hamburg: selected in 1973; tested as CC 65; introd. in 1986. Berry: medium to large; ovoid truncate; firm; crisp; slight muscat flavor. Cluster: medium-large; round; well-filled; numerous shot berries. Vine: vigorous: productive.

Southern Home.- Black interspecific hybrid introd. for ornamental planting in the southern USA. Orig. in Leesburg, Fla., by J.A. Mortensen, J.W. Harris, D.L. Hopkins, and P.C. Andersen. Summit (Vitis rotundifolia) x P9- 15 (a hybrid of $V$. rotundifolia, $V$. popenoei, $V$. munsonima, and $V$. vinifera); selected in 1984; tested as Fla. AA12-3. Plant patent applied for. Berry: oval; medium-large, $6.8 \mathrm{~g}$; 3.4 seeds/berry; pulp breaks up when chewed; scar moderately dry; soluble solids similar to other black muscadines; unique aromatic flavor; berries adhere to vine longer than other muscadines. Cluster: moderately loose; 12.2 berries/cluster. Vine: vigorous; self-fruitful; unique leaf shape with deep-cut sinuses resembling those of maple leaf. No Pierce's Disease has been observed; highly resistant to ripe rot, bitter rot, black rot, anthracnose, and downy mildew.

Tudor Premium Red.- Red, seedless table grape, an early ripening sport of Emperor. Orig. in Delano, Calif., by John A. Buska. Plant patent 6760, 25 Apr. 1989: assigned to Dan Tudor and Sons. Berry: two naturally occurring seed traces per berry that are visually detectable, but following treatment with gibberellic acid and girdling are substantially undetectable: berry large (naturally $4.4 \mathrm{~g}$; treated with gibberellic acid and girdling $5.7 \mathrm{~g}$ ): neutral flavor; crisp. Cluster: large; broad and tapering; well-filled but not compact. Vine: vigorous; productive to very productive: one cluster/shoot usually; fruit matures 10 to 14 days before Emperor.

Tzori.- Triploid, seedless. white table grape. a sport of Perlette. Discovered in 1978 in Nir-Banim. Israel, by Moshe Tzori. Plant patent 62\%. 20 Sept. 1988. Berry: round: medium; seedless; responds to gibberellic acid treatment; green-yellow to yellow; slight muscat flavor. Cluster: medium: less dense than Perlette. Vine: fertile; fastgrowing. Use is intended as fresh market or raisins.

\section{GRAPE ROOTSTOCKS}

\section{John R. Clark \\ University of Arkansas, Fayetteville}

Florilush.- Improved bunch grape rootstock for Florida. Orig. in Leesburg. Fla.. by J.A. Mortensen. J.W. Harris, and D.L. Hopkins. Dogridge x Tampa; selected in 1984; tested as CD9-81. Not patented. Vine (compared to Dog Ridge): higher percentage of successful grafts; lower tendency to sprout below the graft union. More tolerant to grape root borer than Tampa; resistant to Pierce's Disease, anthracnose, downy mildew, powdery mildew, and Isariopsis leaf blight. Highly tolerant to various nematodes; adapted to well-drained soils of Florida.

VR 043-43.- For sites with grape fanleaf virus. Orig. in Davis, Calif., by L.A. Lider, H.P. Olmo, and A.C. Goheen. Plant patent 6319, 4 Oct. 1988; assigned to the Regents of the Univ. of California. Hunisa $\mathrm{x} V$. rotundifolia male No. 2. Vine: immune to feeding by Xiphinema index, the nematode vector of grape fanleaf virus; tolerant to phylloxera; tolerant to most strains of root knot nematode. Asexual propagation by cuttings is improved by application of rooting hormones. Distinguished from its companion rootstock, VR 039-16, in that VR 043-43 is not immune, but only tolerant, to phylloxera.

\section{GRAPEFRUIT}

\section{F.G. Gmitter, Jr., and K.M. Crosby Citrus Research and Education Center, Lake Alfred, Fla.}

Flame.- Orig. in 1973 as a seedling of 'Henderson' grapefruit at A.H. Whitmore Foundation Farm, Leesburg, Fla. Selected by C.J.
Hearn, U.S. Dept. of Agriculture (USDA), Orlando, in 1980. Propagated by C.O. Youtsey, Citrus Budwood Registration Bureau. Introd. by USDA in 1987. Fruit: globose; some external blush; flesh red, darker than 'Ray Ruby' but not as dark as 'Star Ruby'; color holds later than 'Ray Ruby'; seedless. Tree similar to 'Henderson'.

Rio Red.- Orig. in 1963 as a bud sport of A\&I- 1 -48, a selection from irradiated budwood of 'Ruby Red'. Introd. by R.A. Hensz. Texas A\&I, in 1984. Fruit: globose; good external blush; flesh red; five to seven seeds; five times the lycopene content of 'Ruby Red'. Tree: vigorous; precocious; productive; not sensitive to herbicide and foot rot like 'Star Ruby'.

\section{KUMQUAT}

F.G. Gmitter, Jr., and K.M. Crosby

Citrus Research and Education Center, Lake Alfred, Fla.

Centennial.- Orig. as a spontaneous. variegated sport on a twig of US1515 (a seedling of 'Nagami'). at A.H. Whitmore Foundation Farm, Leesburg, Fla. Selected by H.C. Barrett, U.S. Dept. of Agriculture, Orlando. Fruit: ovate; skin variegated grey-yellow/green-yellow when immature, yellow-orange with darker orange regions when mature; moderately acid; juicy. Fruit produced year round. Tree: small, shrubby; upright: dense; thornless: short internodes; leaf variegation variable, tricolored pale yellow/grey-green/dark green.

\section{LIMES}

\section{F.G. Gmitter, Jr., and K.M. Crosby}

Citrus Research and Education Center, Lake Alfred, Fla.

Giant Key.- Orig. as a spontaneous autotetraploid seedling of 'Key' lime. Selected by H.C. Barrett. U.S. Dept. of Agriculture, Orlando. in 1973. Fruit: size large,47 mm, twice as large as 'Key' lime; 7.3\% acid: self-fertile. Tree: shrub-like: semi-upright: continuous flowering and multiple fruit crops: not cold-tolerant.

\section{MANDARINS AND MANDARIN HYBRIDS}

\section{F.G. Gmitter, Jr., and K.M. Crosby}

Citrus Research and Education Center, Lake Alfred, Fla.

Fallglo.- Orig. from a cross of [Citrus reticulata $\mathrm{x}$ (C. paradisi $\mathrm{x}$ C. reticulata)] 'Bower' x (C. reticulata hybrid) 'Temple'. Cross made by P.C. Reese in 1962; introd. in 1987 by C.J. Hearn, U.S. Dept. of Agriculture, Orlando. Fruit: large. 76 to $82 \mathrm{~mm}$; flattened; rind smooth, reddish-orange; resistant to plugging; easily peeled: high juice content $(65.8 \%)$ : 20 to 40 seeds. Matures early to midseason. Tree: vigorous; thornless; foliage light green: more upright than 'Temple'; moderately cold hardy; resistant to citrus scab fungus (Sphaceloma fawcetti).

Sunburst.- Orig. from a 1961 cross of [Citrus reticulata $\mathrm{x}(C$. paradisi $\mathrm{x} C$. reticulata)] 'Robinson' $\mathrm{x}[C$. reticulata $\mathrm{x}(C$. paradisi x $C$. reticulata)] 'Osceola'. Introd. in 1979 by C.J. Hearn, U.S. Dept. of Agriculture, Orlando. Fruit: size medium. 64 to $76 \mathrm{~mm}$; ablate, flattened at stem end; depressed navel: rind thin, dark orange, smooth, easily peeled; flesh dark orange: 10 to 20 seeds; midseason. Tree: moderately vigorous: upright: thornless; foliage dark green. Moderately cold tolerant: tolerant to snow scale; resistant to Alternaria and to scab: susceptible to rust mites.

Sunset.- Orig. from a cross of Citrus reticulata 'Imperial' x (C. reticulata x $C$. sinensis) 'Ellendale'. Cross made in 1963 by $\mathrm{L}$. Stafford, Irymple, Victoria. Australia; tested as C034; introd. in 1991 by 1 . Thornton, M. Edwards, and S. Sykes. Fruit: ablate; slightly larger and higher juice content than Imperial; occasional navel; rind thin. bumpy, easily peeled; flesh orange; few seeds. Early to midseason. Tree: spreading, less upright than 'Imperial': thornless: medium lanceolate leaves. 


\section{NECTARINES}

\section{Wayne B. Sherman University of Florida, Gainesville}

Arctic Pride.- Orig. by C.F. Zaiger, G.N. Zaiger, L.M. Gardner, and G.G. Zaiger, Modesto, Calif. [(Ruby Gold x Redwing) x (O'Henry x Giant Babcock)] F,. Plant patent 8450, 9 Nov. 1993. Fruit: large; nearly globose; skin attractive red; flesh white, firm, melting; freestone; flavor excellent; high soluble solids. Ripens in late season. Flowers: large, showy, pink; leaf glands reniform. Tree: large; vigorous; upright; productive.

Bradcrim.- Synonym for Stark ${ }^{\circledR}$ Crimson Snow $^{\mathrm{TM}}$.

Flame Glo.- Orig. by C.F. Zaiger, G.N. Zaiger, L.M. Gardner, and G.G. Zaiger, Modesto, Calif. [Flamekist x (SunGrand x Merrill Gem) $\left.\mathrm{F}_{2}\right] \mathrm{F}_{3}$. Plant patent 8441, 2 Nov. 1993. Fruit: large; nearly globose with high degree of attractive red skin; flesh light yellow, firm; clingstone with good flavor. Ripens 45 days before FlameKist. Flowers: large, showy, pink; leaf glands reniform. Tree: large; vigorous; upright; productive

Pinta.- Orig. by C.B. Bubani, Fresno, Calif. Larry's openpollinated. Plant patent 8486, 7 Dec. 1993. Similar to Red Jim, but ripens 5 weeks later with brighter color and richer flavor. Fruit: large; ovate; skin $60 \%$ to $90 \%$ red blush over bright yellow ground color; flesh yellow, melting, firm; freestone; red at pit. Flowers: large, showy; leaf glands reniform. Tree: upright-spreading; very productive.

Santa Maria.- Orig. by C.B. Bubani, Fresno, Calif. Larry's openpollinated. Plant patent 8485,7 Dec. 1993. Similar to Fantasia, but ripens 2 weeks later with a brighter red blush, firmer fruit, and enhanced flavor. Fruit: large; globose to oval; $25 \%$ to $60 \%$ red blush with some streaking; flesh light yellow, with red cavity radiating into flesh; melting; freestone. Flowers: large, showy, pink: leaf glands reniform. Tree: hardy; upright-spreading; productive.

Stark ${ }^{\circledR}$ Crimson Snow ${ }^{\mathrm{TM}}$ (Bradcrim).- Orig. by L.G. Bradford and N.G. Bradford, LeGrand, Calif. (Sun Grand x Robin) openpollinated. Plant patent 8461, 16 Nov. 1993. Fruit: size medium; globose, with inconspicuous shallow suture line; skin nearly full-red blush; flesh white, medium firm, melting, nonacidic; freestone; pronounced aroma with very good eating quality. Ripens 1 month after Robin. Flowers: late, large, medium pink; leaf glands globose. Tree: large; vigorous; spreading; very productive.

Suncoast.- Orig. at Florida Agr. Expt. Sta., Gainesville. Complex parentage; tested as Fla. $856 \mathrm{~N}$; released by P.C. Andersen and W.B. Sherman in 1994. Not patented. Released for large size early in season. Fruit: oblong; large; $80 \%$ red blush over yellow ground color; skin tough, with some sugar speckles; flesh firm, sweet, yellow, melting; semi-clingstone at soft ripe. Ripens 7 days after Flordaking, $\approx 75$ days after full bloom. Flowers: small, deep pink, nonshowy; leaf glands reniform. Leaves medium small; tend to roll in autumn. Good resistance to bacterial leafspot. Chilling requirement 400 chill units.

Sunmist.- An early white nectarine with low chilling requirement. Released in 1994 by W.B. Sherman, P.C. Andersen, and P.M. Lyrene, Florida Agr. Expt. Sta., Gainesville, in 1994. Flordaglo peach x Mayfire nectarine; tested as Fla. 88-11 NW. Plant patent applied for. Fruit: round; $90 \%$ red blush over creamy white ground color; skin moderately tough; flesh firm, white, melting, nonbrowning on cut surfaces; semi-clingstone. Ripens $\approx 80$ days after full bloom, $\approx 7$ days before Sunblaze. Flowers: showy, pink; leaf glands globose. Resistant to bacterial leafspot. Chilling requirement 300 chill units.

Sunny Red.- Mutation of Red Jim, found by P. Chiamari and S. R. Hirasuna, Fresno, Calif. Plant patent 8534, 11 Jan. 1994. Fruit: similar to Red Jim but ripening 10 days later; large; ovate with broad groove suture; skin mostly dark red with striping; flesh yellow, melting, firm, dark red at pit; freestone. Flowers: large, showy, pink; leaf glands reniform.

Sunraycer.- Orig. at Florida Agr. Expt. Sta. Cross of complex parentage, tested as Fla. 84-16N. Released in 1994 by W.B. Sherman, P.C. Andersen, and P.M. Lyrene for its large, attractive fruit. Fruit: elongated oval; large; $90 \%$ red blush over bright yellow ground color; flesh firm, yellow, melting, nonbrowning; semi-cling when soft ripe. Few split pits. Ripens 5 days after Sunred, 85 days after bloom.
Flowers: numerous, nonshowy; high fruit set. Leaf glands reniform. Very resistant to bacterial leafspot. Chilling requirement 275 chill units.

Sunsplash.- From 1975 cross made at Florida Agr. Expt. Sta., Gainesville; selected in 1978. Sunlite x ArmKing; tested as Fla. 8-2N. Released in 1993 by G. Krewer, T. Beckman, and W.B. Sherman for its early, attractive fruit. Fruit: oblong; medium size; $60 \%$ red blush over bright yellow ground color; flesh medium firm, yellow, melting, nonbrowning; semi-freestone when soft ripe. Ripens with Sungem, $\approx 80$ days after bloom; high fruit set and fewer split pits than Sungem. Flowers: showy, medium, pink; pollen bright yellow; leaf glands globose. Medium-high resistance to bacterial leafspot. Chilling requirement 400 chill units.

\section{ORNAMENTAL NECTARINE}

Martha Jane.- A red-leaved, double-flowering nectarine, with 18 to 26 petals/flower; orig. at Florida Agr. Expt. Sta., Gainesville. Fla. 15-103 x Fla. 8-23; tested as Fla. 0-2AR. Selected in 1980; named in 1991 by G. Freeman. High flower bud set. Flowers: showy, pink, double; bright red leaves in spring fade to dull red in summer. Fruit small, ripening in mid-July at Gainesville. Resistant to bacterial leafspot. Tree: vigorous, spreading; few fruits produced. Chilling requirement 475 chill units.

\section{ORANGE}

\section{F.G. Gmitter, Jr., and K.M. Crosby}

Citrus Research and Education Center, Lake Alfred, Fla.

Ambersweet.- Orig. from a 1963 cross of [Citrus reticulata 'Clementine' x (C. paradisi $x$ C. reticulata) 'Orlando'] x C. sinensis. Introd. by C.J. Hearn, U.S. Dept. of Agriculture, Orlando, Fla., in 1989. Fruit: size medium, 63 to $95 \mathrm{~mm}$; slightly pyriform; rind moderately thick, pebbly, easily peeled; 0 to 30 seeds; rind and flesh bright orange; early to midseason. Tree: moderately vigorous; upright; dense foliage; some thorns; moderately cold-tolerant.

Cara Cara.- Orig. as a limb sport of Washington navel orange at Hacienda Cara Cara, Valencia Province, Venezuela. Introd. to Florida in 1977 by A.H. Krezdorn through Div. of Plant Industry, Gainesville. Fruit: size and shape comparable to 'Washington'; no red pigmentation in rind; navel sometimes small and inconspicuous; flesh dark red; seedless. Tree: vigorous; some faint variegation on young foliage; cambial tissues may have red pigmentation. Occasional reversion on limbs, producing normal, orange-fleshed fruit.

\section{PEACHES}

\section{Wayne B. Sherman \\ University of Florida, Gainesville}

Aztecgold.- Orig. by Florida Agr. Expt. Sta. in 1984 cross, selected in 1986 by W.B. Sherman, tested as Fla. 86-31c. Named by J. Rodriguez at Chapingo, Mexico, in 1992. [(Mexican cling x Sunred nectarine) $\mathrm{F}_{2}$ ] open-pollinated. Released for fresh fruit market. Fruit: medium size; oval; $60 \%$ attractive red blush over bright yellow ground color; short pubescence; flesh yellow, nonmelting, good flavor; clingstone. Ripens $\approx 5$ days after Diamante, 15 days after TropicSweet. Flowers: nonshowy; leaf glands reniform. Moderately resistant to bacterial leafspot and powdery mildew. Chilling requirement 300 chill units.

FlordaRio.- Orig. by Florida Agr. Expt. Sta. in 1981; selected in 1983; tested as Fla. M3-2; released in 1994 by P.C. Andersen, W.B. Sherman, and R.H. Sharpe. Harken x EarliGrande. Fruit: large; round, with bulging suture; $70 \%$ red blush over bright yellow ground color; flesh firm, melting, yellow; semi-clingstone when soft ripe. Ripens with June Gold, $\approx 92$ days after full bloom. Flowers: nonshowy; globose petiolar leaf glands. Resistant to bacterial leafspot. Chilling requirement 400 chill units.

Laurol.- Mutation of Jerseyqueen, found by D. Reuter in New Jersey. Plant patent 8558, 25 Jan. 1994; assigned to New Jersey Peach 
Council, Clayton. Fruit very large; skin attractive $75 \%$ red skin on orange ground color; slight pubescence; slightly ovate with distinct suture; flesh yellow, firm, melting; freestone, with red streaks radiating from red pit cavity. Ripens 14 days after Jerseyqueen. Flowers: late, large, showy, pink; leaf glands reniform. Tree: very large, vigorous; spreading, willowy; moderately hardy, similar to Jerseyqueen; moderately tolerant to bacterial leafspot.

Regal.- Orig. at Louisiana Agr. Expt. Sta; outstanding for attractiveness of large, early season fruit. From a 1977 cross of Harvester x Surecrop: tested as L77-2-79. Introd. in 1993 by C.E. Johnson, J.T. Payne, W.A. Young, and E.W. Bush. Fruit: medium size; oval, slightly pointed; 65\% smooth red blush over yellow ground color; short pubescence; flesh yellow, firm, melting; semi-free when soft ripe. Ripens 3 days before Bicentennial. Flowers: nonshowy with rosecolored petals; leaf glands reniform. Highly resistant to bacterial leafspot. Chilling requirement $700 \mathrm{~h}$.

Scarlet Snow.- Orig. by C.F. Zaiger, L.M. Gardner, G.N. Zaiger, and G.G. Zaiger, Modesto, Calif. [Golden Supreme open-pollinated x (O'Henry x Giant Babcock)] x (unknown nectarine x Golden Supreme open-pollinated). Plant patent 8439, 26 Oct. 1993. Fruit: large; globose; attractive red blush with short pubescence; flesh white, very firm, melting; freestone. Ripens 35 days after O'Henry. Flowers: medium, nonshowy, pink; leaf glands reniform. Tree: large; vigorous; upright; productive.

Snow King.- Orig. by C.F. Zaiger, L.M. Gardner, G.N. Zaiger, and G.G. Zaiger, Modesto, Calif. (Unknown nectarine $\mathrm{x}$ Redwing) $\mathrm{x}$ (O'Henry open-pollinated). Plant patent 8415, 12 Oct. 1993. Fruit: large; nearly globose; nearly covered with attractive red blush; moderate pubescence; flesh white, very firm, melting; excellent flavor; freestone. Ripens 5 or 6 days after O'Henry. Flowers: large, showy, pink; leaf glands reniform. Tree: large, vigorous; upright; productive.

Special Red July.- Mutation of Spring Red nectarine, found by F.E. Viscarra, Readley, Calif. Plant patent 8597, 15 Feb. 1994. Similar to Elegant Lady, but ripens 2 weeks later, and to O'Henry, but ripens I week earlier. Skin: $70 \%$ to $95 \%$ red blush; blush slightly duller than Elegant Lady; more speckling and russetting than occurs on Elegant Lady or O'Henry. Fruit: large; flesh yellow, with red radiating from pit; melting; freestone. Flowers: medium, nonshowy, bright pink; leaf glands reniform. Tree: vigorous; upright-spreading; productive.

StanisLaus.- Dual-purpose peach orig. by C.F. Zaiger, L.M. Gardner, G.N. Zaiger, and G.G. Zaiger, Modesto, Calif. Carolyn x Loadel. Plant patent 8376, 14 Sept. 1993. Fruit: large; nearly globose; moderate pubescence; flesh yellow, very firm, nonmelting; clingstone. Ripens 7 or 8 days after Loadel. Flowers: small, nonshowy, pink; leaf glands globose. Tree: vigorous; semi-upright; productive.

Sugar Giant.- Orig. by C.F. Zaiger, G.N. Zaiger, L.M. Gardner, and G.G. Zaiger, Modesto, Calif. (Unknown nectarine x Royal Gold) x [O'Henry open-pollinated x (MayGrand open-pollinated x Sam Huston)]. Plant patent 8442, 2 Nov. 1993. Fruit: large; globose; light red blush over white ground; medium pubescence; flesh white, firm, melting; freestone. Ripens 1 week before Giant Babcock. Flowers: large, showy, pink; leaf glands reniform. Tree: large; vigorous; upright; productive.

Thiara.- Chance seedling found by S. Thiara, Yuba City, Calif. Plant patent 8744, 24 May 1994. Similar to Loadel, but ripening 8 days earlier, with longer fruit and more oblate shape. Fruit: blush has 5\% to $40 \%$ red, with light striping common; medium large; medium pubescence; flesh yellow; clingstone. Flowers: nonshowy; leaf glands globose. Tree: vigorous; upright-spreading; productive.

\section{PEACH ROOTSTOCKS}

\section{W.B. Sherman and Dale E. Kester}

Adarcias.- Orig. by M.A. Moreno and R. Cambra, Est. Exp Aula Dei (CSIC), Zaragoza, Spain. Open-pollinated seedling of almond (Prunus dulcis) and peach (P. persica). Selected in 1970. Roots by hardwood cuttings and can be produced by in vitro techniques. As rootstock, produces less vigor $(2 / 3$ size) than similar peach-almond hybrids (e.g., GF 677 and Adafuel), but shows equally high productivity index in tests with peach cultivars. Adapted to light and calcareous soils, but requires good drainage. Graft compatible with peach, almond, and Japanese plum ( $P$. salicina) (limited range tested). Variable compatibility with European plum $(P$. domestica). Leaves are peachlike, internodes are intermediate. One-year-old shoots green in summer and intensely red in winter. Bloom on current-season shoots (like peach). Flowers: large, showy, light pink. Fruit is intermediate between peach and almond.

BY520-9.- Orig. by U.S. Dept. of Agriculture, Byron, Ga.; released jointly with Clemson Univ. in 1994 for extending tree life in situations where peach tree short life syndrome has been a major problem. ([(S-37 open-pollinated) x Nemaguard] open-pollinated $]$ open-pollinated produced siblings that are planted and harvested in bulk for the BY520-9 rootstock line. Seedlings appear to have resistance to Criconemella xenoplex, Meloidogyne incognita, and $M$. javanica nematodes. Plant variety protection applied for.

\section{ORNAMENTAL PEACH}

\section{Wayne B. Sherman University of Florida, Gainesville}

Tom Thumb.- Brachytic dwarf with persistent dark red foliage, orig. by J.N. Moore. Tsukuba No. 2 open-pollinated. Plant patent 8509, 28 Sept. 1993; assigned to Univ. of Arkansas, Fayetteville. Fruit: small; very pubescent; poor eating quality; semi-clingstone. Flowers: showy, double, pink-red.

\section{PEACH x PLUM HYBRID}

\section{Wayne B. Sherman University of Florida, Gainesville}

Tri-Lite.- Orig. by C.F. Zaiger, G.N. Zaiger, L.M. Gardner, and G.G. Zaiger, Fresno, Calif. O'Henry x [mixture of three pollens from (Red Beaut plum x unknown peach)]. Plant patent 8393, 28 Sept. 1993. A regular and productive bearer of round, medium-size, very firm, clingstone, very short pubescent, white-fleshed fruit with good flavor and ability to hang on the tree 12 to 15 days in late June. Flesh clearing when canned. Flowers: showy, pink; leaf glands reniform. Tree: large; vigorous; upright.

\section{PEARS}

\section{Joseph D. Postman and Kim E. Hummer U.S. Department of Agriculture National Clonal Repository, Corvallis. Ore.}

Butirra Precoce Morettini.- An early season, high-quality dessert variety developed in Florence, Italy, by A. Morettini. Introd. in 1956. Coscia x Bartlett; ("butirra" = buttery, "precoce" = early). Fruit: medium to large; pyriform, but not as uniform as Bartlett; skin greenyellow with red blush, thin; flesh white, melting, juicy, sweet. Ripens 20 days before Bartlett; storage 1 to 2 months. Tree: vigorous; productive. Graft compatible on quince.

Concorde.- A precocious, midseason variety similar to Conference. Orig. at East Malling Research Station, Kent, U.K. Conference x Doyenne du Cornice. Introd. by F.H. Alston in 1987; in U.S., propagation rights assigned to TRECO, Woodburn, Ore. Fruit: longpyriform, large, similar to Conference; excellent skin finish with less russet than Conference; good, fresh eating quality. Harvest maturity mid-September, 2 weeks after Conference. Stores in air at $-1 \mathrm{C}$ for 6 months; storage life better than Cornice, not as good as Conference. Blooms between Conference and Doyenne du Cornice; both parents and Bartlett are suitable pollenizers. Tree: spreading, with wide crotch angles; precocious; early yields superior to either parent. Produces few secondary blossoms.

Conference.- A standard for midseason dessert pears in western Europe. Orig. at Sawbridgeworth, England, by Thos. Rivers and Sons and introd. in 1894. Open-pollinated seedling of Leon LeClerc de Laval. Exhibited at the National British Pear Conference in 1885, for which it was later named. Fruit: medium to large size: long pyriform; 
skin smooth, green, unevenly russetted; flesh pale yellow with pink tinge, tender, melting, very juicy, sweet. Season October and November; good storage life. Cropping early, regular, heavy; tends to produce misshapen parthenocarpic fruit. Self-fertile, diploid; good pollen. Tree: moderately vigorous. Susceptible to fire blight.

Flamingo.- An attractive, early midseason dessert variety introduced in Republic of South Africa in 1993. Bon Rouge (a red sport of Bartlett) x Forelle; released by Infruitec. Fruit: size medium-small, $150 \mathrm{~g}$; oblong-ovate; skin light yellow with distinctive red blush and conspicuous lenticels; flesh creamy white, soft texture, good flavor. Harvest maturity early February in the Western Cape. Tree: vigorous; productive; tendency to produce a few thorny shoots; moderate chilling requirement. Packhams Triumph and December are suitable pollinizers.

\section{PEAR ROOTSTOCKS}

\section{Joseph D. Postman and Kim E. Hummer U.S. Department of Agriculture National Clonal Repository, Corvallis, Ore.}

BP-1.- A semi-dwarfing, precocious rootstock from Republic of South Africa. Grown from seed of a wild pear tree at Elsenberg in 1928. Selected and evaluated by A.F. deWet at Fruit and Fruit Technology Research Inst., Stellenbosch; released in 1974. Propagated with some difficulty by hardwood cuttings. Susceptible to fire blight.

BP-2.- A clonal rootstock introd. in Republic of South Africa in 1974. From seed taken from wild pear tree in Elsenberg in 1928. Selected and evaluated by A.F. deWet, Fruit and Fruit Technology Research Inst., Stellenbosch. Trees on BP-2 are standard size, precocious.

BP-3.- A clonal pear rootstock introd. in Republic of South Africa in 1979. From seed taken from wild pear tree in Elsenberg in 1928. Selected and evaluated by A. F. deWet, Fruit and Fruit Technology Research Inst., Stellenbosch. Trees on BP-3 are standard size, precocious and very productive. Adaptable to variety of soil types, from sandy loam to clay loam. Hardwood cuttings propagate satisfactorily with bottom heat. Susceptible to fire blight.

\section{PLUMS}

\section{D.W. Ramming \\ U.S. Department of Agriculture Horticultural Crops Research Laboratory, Fresno, Calif.}

Akihime.- Chance seedling found in Aikawa, Sukawa, Yuzawa City, Akita prefecture, Japan, by Shoichiro Kojima; assigned to Nakajima Tenkoen Co. Plant patent 7858, 28 Apr. 1992. Fruit: round to ovoid with slightly pointed apex, very large, 150 to $200 \mathrm{~g}$; skin purplish-red on yellow ground color; flesh yellow, juicy, medium firmness, high sugar $13.7^{\circ}$ Brix; matures with Kelsey. Blossom: small. Tree: vigorous; upright to spreading; low self-fertility requiring pollinator like Oishi Wase.

Aleta Rose.- Bud sport of Simka found in Dinuba, Calif., by Loretta J., Phillip D., and Alfred W. Strohmaier. Plant patent 5231, 15 May 1984. Fruit: globose to cordate; medium to large. $57 \mathrm{~mm}$; skin $90 \%$ to $100 \%$ red-purple; flesh yellow; stone semi-free. In central San Joaquin Valley, ripens 10 days before Simka, about 25 to 29 June. Blossom: medium, white, blooms late. Tree: vigorous; upright to spreading; partially self-fertile.

AP-3.- Bud sport of Laroda found in Dinuba, Calif., by Alvin Peters. Plant patent 5074, 26 July 1983. Fruit: globose; medium size, $56 \mathrm{~mm}$; skin red blush over orange-yellow ground color; flesh yellow; clingstone. In central San Joaquin Valley, ripens 6 to 7 weeks after Laroda, about 25 Aug. to 5 Sept. Blossom: medium, white. Tree: vigorous; semi-spreading.

Autumn Beaut .- Orig. in Modesto, Calif., by Chris, Gary, and Grant Zaiger and Leith Gardner. (Roysum open-pollinated) x Eldorado. Plant patent 8189, 30 Mar. 1993. Fruit: globose to slightly oblate; large, $64 \mathrm{~mm}$; skin maroon to blackish-blue; flesh light yellow, firm; clingstone; does not crack. In central California ripens 6 days before Roysum. Blossom: small to medium; white. Tree: vigorous; upright productive; self-infertile.

Autumn Pride.- Orig. in Modesto, Calif., by Chris, Gary, and Grant Zaiger and Leith Gardner. Friar x (Mariposa x Ebony). Plant patent 7843, 31 Mar. 1992. Fruit: globose, slightly flattened; large, 64 to $67 \mathrm{~mm}$; skin purple; flesh pale yellow; stone semi-free. In central California, ripens 7 to 10 days after Roysum, about the last week of September. Blossom: medium, white, blooms $\approx 2$ days after Santa Rosa. Tree: vigorous; upright; productive.

Betty Anne.- Orig. in Modesto, Calif., by Chris, Gary, and Grant Zaiger and Leith Gardner. ([Friar x (Mariposa x Ebony)] x Autumn Giant]. Plant patent 8471, 23 Nov. 1993. Fruit: nearly globose, slightly flattened at base and on suture side; large, 58 to $64 \mathrm{~mm}$; skin red with yellow ground color; flesh yellow white, firm with mild flavor; clingstone. In central California, ripens the last of August. Blossom: medium, white. Tree: vigorous; upright; productive.

Bill Hengst October Gem.- Chance seedling found in Exeter, Calif., by William E. Hengst. Plant patent 7348, 9 Oct. 1990. Fruit: ovate; medium-large, $62 \mathrm{~mm}$ : skin Princeton; flesh Princeton; clingstone. In central San Joaquin Valley, ripens 4 weeks after Casselman. Blossom: small, white. Tree: medium vigor; upright; productive.

Black Gold ${ }^{\mathrm{TM}}$ (Suplumtwelve).- Orig. by John H. Weinberger; assigned to Superior Farming Co. Angeleno open-pollinated. Plant patent 4965, 14 Dec. 1982. Fruit: globose; medium size, $61 \mathrm{~mm}$; skin dark purple; flesh red; stone semi-free. In central San Joaquin Valley, ripens with Eldorado, about 30 June to 8 July. Blossom: medium, white. Tree: medium vigor; spreading; very productive.

Black Noble.- Orig. in Le Grand, Calif., by Norman and Glen Bradford. Red Beaut x unnamed seedling; cross made in 1983. Plant patent 7504, 23 Apr. 1991. Fruit: symmetrical, obovoid; medium size, $54 \mathrm{~mm}$; skin very shiny, dark reddish-purple; flesh strong red, crispy, and extremely firm; flavor acidic and very sweet, juicy; clingstone. In central California, ripens between Black Beaut and Santa Rosa. Blossom: small; white; blooms with and pollinated by Wickson. Tree: vigorous; upright; self-unfruitful; productive.

Black Premium ${ }^{\text {TM }}$ (Suplumsixteen).- Orig. by John H. Weinberger and Tim P. Sheehan, assigned to Sun World. Queen Rosa x El Dorado. Introd. in 1991. Plant patent 7574, 2 July 1991. Fruit: ovate with pointed blossom end; medium size, $60 \mathrm{~mm}$; skin red-black; flesh yellow. In central San Joaquin Valley, ripens with Blackamber. Tree: medium vigor; semi-upright; regular bearing; medium productive.

Black Ruby.- Orig. in Byron, Ga., by V.E. Prince and J.M. Thompson. BY4-95 open-pollinated seed planted in 1975. BY4-95 is thought to be from seed of Queen Ann x Santa Rosa. Selected in 1978 and tested as BY7404-1. Fruit: round to oblate; medium size, $50 \mathrm{~mm}$; skin reddish-black; flesh yellow, firm, good quality; freestone. In Georgia. ripens 1 week after Santa Rosa and Morris. Blossom: white with orange-red anthers; pollinated by Rubysweet, AU-Rubrum, and Methley. Tree: moderately vigorous and upright; productive; selfunfruitful. Moderately resistant to bacterial spot and bacterial canker, tolerant to plum leaf scald.

Blue Knight.- Orig. in Modesto, Calif., by Chris, Gary, and Grant Zaiger and Leith Gardner. (Red Beaut open-pollinated) open-pollinated. Plant patent 5813, 2 Dec. 1986. Fruit: globose; medium size, larger than Red Beaut, $54 \mathrm{~mm}$; skin blackish-blue; flesh yellow, firm; clingstone. In central California, ripens 10 days after Red Beaut, about 13 to 19 June. Blossom: medium, white. Tree: vigorous; upright; productive.

Bradgreen.- Synonym for Green Sweet ${ }^{\mathrm{TM}}$.

Compact Friar.- Orig. in San Joaquin County, Calif., by Henry G. Wong. Irradiated mutation of Friar. Plant patent 8103, 19 Jan. 1993. Fruit: ablate; large, 43 to $46 \mathrm{~mm}$; skin purplish-black, same color as Friar; flesh orange-yellow, firm, mild sweet. Ripens with Friar. Blossom: medium, white. Tree: medium vigor, dwarf, half the size of Friar; upright but not as much as Friar; self-unfruitful.

Crimson Nugget.- Orig. in Del Rey, Calif., by Frank T. Matoba. Red Beaut open-pollinated. Plant patent 8038, 27 June 1991. Fruit: ovate; small size; skin dark red. In central San Joaquin Valley, ripens 5 days before Red Beaut. 
Del Rey Sun.- Orig. in Del Rey, Calif., by Thomas O. Chamberlin, Sr.; assigned to Metzler Investments and Metropolitan Life Insurance Co. Open-pollinated seedling of unknown origin. Plant patent 6991 , 22 Aug. 1989. Fruit: round; medium, 54 to $64 \mathrm{~mm}$; skin black; flesh yellow; freestone. In central San Joaquin Valley, ripens about 15 to 20 June. Blossom: white, one flower per bud. Tree: vigorous; upright; appears self-fertile.

Dolly.- Orig. in Modesto, Calif., by Chris, Gary, and Grant Zaiger and Leith Gardner. Red Beaut open-pollinated. Plant patent 6071, 29 Dec. 1987. Fruit: large size, 54 to $58 \mathrm{~mm}$; ovate, elongated at apex; skin yellow; flesh yellow; clingstone. In central San Joaquin Valley, ripens 1 month after Red Beaut, about 6 to 11 July. Blossom: small to medium, white. Tree: vigorous; upright; self-unfruitful; production moderate.

Earliqueen.- Orig. in Modesto, Calif., by Chris, Gary, and Grant Zaiger and Leith Gardner. Open-pollinated seedling of 61EC540 (unknown plum open-pollinated). Plant patent 8583, 8 Feb. 1994. Fruit: large size, 60 to $73 \mathrm{~mm}$; globose; skin garnet-red to Bordeauxred, becoming maroonish blue-black when overripe; flesh yellowishwhite to pale yellow, firm; clingstone. In central San Joaquin Valley, ripens $\approx 2$ days after Red Beaut, about 25 May to 2 June. Blossom: medium, white. Tree: vigorous; upright.

First Beaut.- Mutation of Red Beaut found in Tulare County, Calif., by Charles H. Neufeld. Plant patent 7335, 25 Sept. 1990. Fruit: ovate; medium size, $46 \mathrm{~mm}$; skin red-purple; flesh amber-yellow, firm, juicy; stone semi-cling. In central San Joaquin Valley, ripens 5 days before Red Beaut. Blossom: average size, white, pollen sterile. Tree: vigorous; upright and broadly spreading.

Flavorich.- Orig. in Modesto, Calif., by Chris, Gary, and Grant Zaiger and Leith Gardner. Friar x 27EB 180[60G866(Autumn Rose x Queen Ann) x unknown plumcot]. Plant patent 8546, 18 Jan. 1994. Fruit: size large, 62 to $76 \mathrm{~mm}$; globose to slightly oblate; skin deep magenta to dark blue ground overspread with dark violet to blackishblue; flesh dark yellow to light orange, firm; $20^{\circ}$ Brix at maturity; quality excellent; clingstone. In central San Joaquin Valley, ripens 7 weeks after Friar, about 15 to 20 Sept. Blossom: medium, white. Tree: vigorous; upright.

Gar-Belmont.- Orig. in Fresno, Calif., by John M. Garabedian. Open-pollinated seedling of unknown origin. Plant patent 7159, 20 Feb. 1990. Fruit: oblate; medium size, 57 to $59 \mathrm{~mm}$; skin very dark red; flesh cream to pale yellow; stone semi-free. In central San Joaquin Valley, ripens 5 days after Early Gar Rosa, about 1 to 10 June. Blossom: average, pink. Tree: average vigor; spreading; productive.

Green Sweet ${ }^{\mathrm{TM}}$ (Bradgreen).- Orig. in Le Grand, Calif., by Norman and Glen Bradford. (Black Beaut open-pollinated) openpollinated. Plant patent 8498, 14 Dec. 1993. Fruit: oblate; medium size, $60 \mathrm{~mm}$; skin strong yellow-green; flesh light yellow-green, extremely firm and crisp; flavor very sweet with medium acidity, 18 to $22^{\circ}$ Brix, very juicy; stores very well. In central California, ripens with Angeleno. Blossom: medium, white, blooms early; pollinated by Ambra. Tree: vigorous; spreading; very productive; self-unfruitful.

Gypsy Red.- Orig. in Reedley, Calif., by James W. Taylor; assigned to Ito Packing Co. Open-pollinated seedling of Elephant Heart. Plant patent 7119, 23 Jan. 1990. Fruit: round; medium size, 67 $\mathrm{mm}$; skin reddish-purple with yellow-greenish ground color; flesh red, very sweet with less acid than Satsuma; clingstone. In central San Joaquin Valley, ripens about 5 to 15 Aug. Blossom: medium, white; anthers yellow. Tree: vigorous; upright; productive; self-infertile.

Jake's Best.- Orig. in Fresno, Calif., by John M. Garabedian. Open-pollinated seedling of unknown origin. Plant patent 7148, 13 Feb. 1990. Fruit: oblate, one cheek generally slightly larger than the other; medium size, $47 \mathrm{~mm}$; skin dark red; flesh Cardinal; stone semifree. In central San Joaquin Valley, ripens 2 weeks before Wuhl, about 27 May to 3 June. Blossom: average, white, blooming with Red Beaut. Tree: medium vigor; upright; productive.

JD-1.- Orig. in Modesto, Calif., by John D. Young; assigned to Young Family Trust. Purchased as budded ornamental plum tree of unknown origin. Plant patent 5926, 7 Apr. 1987. Growth closely resembles flowering Blireiana. Fruit: ovoid; small, larger than Blireiana, $54 \mathrm{~mm}$; skin wine-red, glabrous; flesh deep red; freestone. Ripens 10 to 14 days before Hollywood. Leaves: a deeper bronze-purplish color than Blireiana. Blossom: single, white with pink tinge. Tree: vigorous; upright.

John-John.- Orig. in Fresno, Calif., by John M. Garabedian. Open-pollinated seedling of unknown origin. Plant patent 5906, 17 Mar. 1987. Fruit: globose to slightly oblate; one half often larger apically; medium to large, 57 to $60 \mathrm{~mm}$; skin purplish-red, bitter; flesh light amber-yellow; stone semi-free. In central San Joaquin Valley, ripens 7 to 10 days before Laroda, about 6 July. Blossom: medium, white. Tree: vigorous; upright spreading; very productive.

June Beaut.- Orig. in Le Grand, Calif., by Norman and Glen Bradford. El Dorado open-pollinated. Plant patent 5662, 18 Feb. 1986. Fruit: oblate; medium size, $51 \mathrm{~mm}$; skin dark maroon, only slight tendency to crack; flesh greenish-yellow; clingstone. In central California, ripens 3 to 5 days after El Dorado. Blossom: medium, white, blooms 5 days after El Dorado. Tree: vigorous; upright; regular bearing; very productive; self-infertile.

Majestic M.- Bud sport of Friar found in Orosi. Calif., by Mere1 R. Butts. Plant patent 6975, 8 Aug. 1989. Fruit: round; medium size, 56 to $59 \mathrm{~mm}$; skin blackish-purple, slight tendency to crack; flesh orange-brown; freestone. In central San Joaquin Valley, ripens 2 to 3 weeks after Angeleno, about second to third week of October. Blossom: small, white. Tree: semi-spreading.

Midrosas.- Bud sport of Late Santa Rosa found in Fresno, Calif. by John D. Pakchoian; assigned to Pakchoian Farms. Plant patent 5416, 12 Mar. 1985. Fruit: round; medium, $50 \mathrm{~mm}$; skin reddishpurple, no suture stripe as in Late Santa Rosa; flesh yellow to yellowred; clingstone. In central San Joaquin Valley, ripens 10 to 15 days before Late Santa Rosa, about 25 June. Blossom: medium, white; anthers yellow. Tree: vigorous; upright to upright-spreading.

Mr. Paul.- Bud mutation of Queen Rosa found in Fresno, Calif., by Ronald Paul. Plant patent 5413, 12 Mar. 1985. Fruit: oblate; large, $65 \mathrm{~mm}$; skin red to red-purple on yellow to yellow-green ground color; flesh very light yellow-amber; clingstone. In central San Joaquin Valley, ripens 1 month after Queen Rosa, about the third week of July. Blossom: late blooming. Tree: vigorous; very upright; productive.

Prima Black Plum S-25.- Orig. in Sanger, Calif., by Michael R. Gerawan. Open-pollinated seedling of unknown origin. Plant patent 8067, 22 Dec. 1992. Fruit: round; medium size, 52 to $57 \mathrm{~mm}$; skin black; flesh yellow to red under skin; clingstone. In central San Joaquin Valley, ripens 4 to 6 days after Red Beaut, about 1 June. Blossom: medium to large, white; anthers yellow with red-orange tinge; blooms early with Ambra. Tree: medium; upright to uprightspreading.

Prima Black Plum 8.15.- Orig. in Sanger, Calif., by Michael R. Gerawan. Open-pollinated seedling of unknown origin. Plant patent 8068, 22 Dec. 1992. Fruit: globose to slightly oblate with a pronounced point; large size, 66 to $71 \mathrm{~mm}$; skin Catawaba; flesh Nankeen; freestone. In central San Joaquin Valley. ripens 2 weeks after Friar, about the first week of August. Blossom: medium, white; anthers yellow. Tree: medium size; upright to spreading; productive.

Prima Red Plum 9-1.- Orig. in Sanger, Calif., by Michael R. Gerawan. Open-pollinated seedling of unknown origin. Plant patent 8057, 8 Dec. 1992. Fruit: oblate; large size, 73 to $80 \mathrm{~mm}$; skin red; flesh cream; stone semi-free. In central San Joaquin Valley, ripens 7 to 10 days after Angeleno, about the second week of September. Blossom: medium, white; anthers yellow-orange with red margins: blooms early with Blackamber. Tree: upright to upright-spreading.

Punian.- Bud sport of French Prune found in Yuba City, Calif., by Gurbachan Punian. Plant patent 7168, 27 Feb. 1990. All characteristics are the same as French Prune, except the fruit ripens 15 to 18 days earlier and the sugar content (30\% to $31 \%$ ) is higher at harvest. Fruit: ovate; medium size, 21 to $24 \mathrm{~g}$ fresh weight, 8.8 to $9.2 \mathrm{~g}$ dry weight; pronounced cavity; skin deep blue; flesh yellow to amber; stone medium to small, cling. Blossom: white, blooms with French Prune. Tree: vigorous; upright.

Purple Majesty.- Orig. in Le Grand, Calif., by Norman and Glen Bradford. Red Beaut x unnamed seedling; cross made in 1982. Plant patent 7503, 23 Apr. 1991. Fruit: symmetrical, oblate; medium size, 60 $\mathrm{mm}$; skin dark reddish-purple; flesh orange-yellow, very firm; flavor mild and very sweet, juicy; clingstone. In central California, ripens approximately with Santa Rosa. Blossom: small; white; blooms with 
and pollinated by Wickson. Tree: vigorous; upright; productive; selfunfruitful.

Ranch 9 Maroon.- Orig. in Fresno, Calif., by John M. Garabedian. Open-pollinated seedling of unknown origin. Plant patent 5902, 17 Mar. 1987. Fruit: oblate; medium, $60 \mathrm{~mm}$; skin deep maroon; flesh deep red; stone semi-free. In central San Joaquin Valley, ripens with Roysum, about 8 Sept. Blossom: medium, white. Tree: medium; upright-spreading; productive.

Ray's Hope.-Bud sport of Casselman found in Exeter, Calif., by Arthur R. Casselman. Plant patent 5650, 28 Jan. 1986. Fruit: ovoid to oblong; medium-small size, $48 \mathrm{~mm}$; skin dark red on yellow ground color; flesh light yellow-amber, firm; clingstone. In central San Joaquin Valley, ripens 4 to 5 weeks after Casselman, about 10 Sept. to 3 Oct. Tree: vigorous; upright-spreading; very productive.

Red Giant $^{\mathrm{TM}}$ (Suplumeighteen).- Orig. in Fresno, Calif., by John H. Weinberger and Tim P. Sheehan; assigned to Sun World. Queen Rosa open-pollinated. Plant patent 7443, 12 Feb. 1991. Fruit: globose to ablate; large size, $60 \mathrm{~mm}$; skin red purple; flesh red; stone semi-free. In central San Joaquin Valley, ripens 2 weeks before Queen Rosa. Blossom: average, white, early. Tree: average vigor; upright; productive.

Red Noble.- Orig. in Le Grand, Calif., by Norman and Glen Bradford. Open-pollinated seedling of an unnamed seedling. Plant patent 7975, 15 Sept. 1992. Fruit: globose to slightly obovoid; medium size, $54 \mathrm{~mm}$; skin dark purplish-red; flesh light yellow, firm; flavor very sweet with medium acidity; very juicy. In central California, ripens $\approx 3$ days before Red Beaut. Blossom: medium; white; blooms early; pollinated by Ambra. Tree: vigorous; upright; medium productive; self-unfruitful.

Royal Diamond.- Orig. in Kingsburg, Calif., by Larry Kitahara; assigned to Kitahara Farms. Open-pollinated seedling of unknown origin. Plant patent 6756, 25 Apr. 1989. Fruit: oblate to round; large size, $59 \mathrm{~mm}$ : skin blue-black to dark blood-red; flesh light yellow amber; stone semi-free. In central San Joaquin Valley, ripens 3 to 4 weeks after Friar, about 17 to 27 Aug. Blossom: medium, white; anthers red-orange; late blooming, with Simka. Tree: medium vigor; very upright; productive.

Royal Star.- Orig. in Kingsburg, Calif., by Lawrence K. and Kei Kitahara. Open-pollinated seedling of unknown origin. Plant patent 7192, 13 Mar. 1990. Fruit: ovate; large size, 56 mm; skin dark blueblack; flesh pink to red, firm, mediumjuicy; clingstone. In central San Joaquin Valley, ripens with Angeleno. Blossom: medium, white. Tree: vigorous; upright to spreading.

Sharron's.- Bud sport of Grand Rosa found in Sanger, Calif., by Giovanni B. Bubani; assigned to R.E.U.S., Pruner A.G.I, Pruner A.G.II, and Agri-Cal. Plant patent 6380, 8 Nov. 1988. Fruit: globose to ovate; large size, 58 to $61 \mathrm{~mm}$; skin dark red, resistant to cracking; flesh yellow, resistant to heat damage; stone semi-free. In central San Joaquin Valley, ripens 4 days before Casselman, about 26 July to 18 Aug. Blossom: large, white; anthers light yellow; midseason. Tree: vigorous; upright.

Showtime.-Orig. in Modesto, Calif., by Eric Wuhl. Open-pollinated seedling of Santa Rosa. Plant patent 8037, 24 Nov. 1992. Fruit: size large, 58 to $62 \mathrm{~mm}$; globose to ovate; skin red-purple; flesh yellow-red, firm; freestone. In central San Joaquin Valley, ripens with SantaRosa, about 18 to 25 June. Blossom: small, white. Tree: upright.

Spring Beaut.- A bud sport of Red Beaut found by Chris Zaiger in Modesto, Calif. Plant patent 4394, 13 Mar. 1979. Fruit: size medium, $54 \mathrm{~mm}$; globose to ovate; skin red; flesh yellow; clingstone. In central San Joaquin Valley, ripens 2 or 3 days before Red Beaut, about 1 to 8 June. Blossom: white, medium. Tree: vigorous; upright.

Summer Treat.- Orig. in Chico, Calif., by Elmer Nilsson; assigned to Nancy Nilsson. Unknown origin; purchased as a budded Santa Rosa tree. Plant patent 8693, 19 Apr. 1994. Fruit: round to oval; medium size, 49 to $54 \mathrm{~mm}$; skin light apple-red to deep mahogany; flesh amber-yellow, firm, dense. Ripens 2 to 4 weeks after Santa Rosa. Can remain on the tree until September. Blossom: medium, white; anthers yellow-gold. Tree: vigorous; upright to upright-spreading; good production; self-fruitful.

Suplumeighteen.- Synonym for Red Giant ${ }^{\mathrm{TM}}$.

Suplumseventeen.- Synonym for Tokay $\operatorname{Red}^{\mathrm{TM}}$.
Suplumsixteen.- Synonym for Black Premium ${ }^{\mathrm{TM}}$.

Suplumtwelve.- Synonym for Black Gold ${ }^{\mathrm{TM}}$.

Suplumtwenty.- Orig. in Madera County, Calif., by John H. Weinberger; assigned to Sun World, Inc. Suplumeleven x Queen Rosa. Plant patent 8363, 7 Sept. 1993. Fruit: oblate; 64 mm; skin redblack; flesh yellow; clingstone. In central California, ripens 2 weeks before Suplumeleven, about mid- to late June. Blossom: white, medium; anthers yellow with shadings of red. Tree: medium vigor; upright; very productive.

SweetDelight.- Orig. in Reedley, Calif., by Jonathan P. Chakerian. Casselman x unknown pollen source. Plant patent 6824, 30 May 1989. Fruit: elliptical; medium to small size, $54 \mathrm{~mm}$; skin dark red; flesh yellow; stone semi-free to cling. In central San Joaquin Valley, ripens 3 weeks before Roysum, about 8 to 20 Sept. with $19 \%$ to $21.5 \%$ sugar. Blossom: medium, white-yellow; blooms 7 to 8 days after Casselman. Tree: vigorous; upright; very productive; appearing self-fertile.

Sweet Gypsy.- Orig. in Reedley, Calif., by James W. Taylor; assigned to Ito Packing Co., Inc. Mariposa open-pollinated. Plant patent 6816, 23 May 1989. Fruit: round; medium to small size, $54 \mathrm{~mm}$; skin reddish-purple; flesh red, very sweet with pleasant acid; clingstone. In central San Joaquin Valley, ripens 1 week before Mariposa, about 28 June to 10 July. Blossom: medium, white; anthers yellow; blooms with Santa Rosa. Tree: vigorous; spreading; productive.

Sweet Heart.- Orig. in Reedley, Calif., by Jonathan P. Chakerian. Casselman x unknown pollen source. Plant patent 5724, 22 Apr. 1986. Fruit: 54 to $56 \mathrm{~mm}$; ovate; skin dark reddish-purple; no observed tendency to crack; flesh amber with red under the skin, firm; semifreestone. Ripens with Casselman. Blossom: light pink. Tree: medium vigor.

Sweet Queen.- Bud sport of Queen Ann found in Kingsburg, Calif., by David C. Vart. Plant patent 8557, 25 Jan. 1994, Fruit: slightly elongated; large, 58 to $61 \mathrm{~mm}$; skin bright green; flesh light yellowgreen, firm, resistant to bruising, mild flavor; clingstone. In central San Joaquin Valley, ripens 1 to 5 July. Blossom: white. Tree: very vigorous.

Tokay $\operatorname{Red}^{\mathrm{TM}}$ (Suplumseventeen).- Orig. in Fresno, Calif., by John H. Weinberger and Tim P. Sheehan; assigned to Superior Farming Co. Queen Rosa open-pollinated. Plant patent 7355, 16 Oct. 1990. Fruit: globose to oblate; large, $60 \mathrm{~mm}$; skin dark purple-black; flesh yellow, juicy, average to fine; clingstone. In central San Joaquin Valley, ripens with Black Beaut. Blossom: small, white, average bloom time. Tree: average vigor; spreading; productive.

Unnamed.- Orig. in Le Grand, Calif., by Fred Anderson. Red Beaut open-pollinated. Plant patent 4823, 9 Feb. 1982. Fruit: globose; medium size, $54 \mathrm{~mm}$; skin deep purple; flesh yellow; clingstone. In central California, ripens 1 week after Red Beaut, about 24 to 30 May. Blooms with Red Beaut. Tree: spreading; productive.

Unnamed.- Bud sport of Nubiana found in Fresno, Calif., by John M. Garabedian. Plant patent 5137, 15 Nov. 1983. Fruit: oblate; small size, $47 \mathrm{~mm}$; skin black, slightly bitter, slight tendency to crack on tip; flesh light cream to yellow, ripens tip first; stone semi-free. In central San Joaquin Valley, ripens 1 week before Red Beaut, about 14 to 21 May. Blossom: white; blooms 7 to 10 days before Red Beaut. Tree: vigorous; upright.

Viking Pride.- Bud sport of Durado found in Kingsburg, Calif., by Joseph W. Satterstrom. Plant patent 6712, 4 Apr. 1989. Fruit: oblate; medium to large, 49 to $60 \mathrm{~mm}$; skin dark red; flesh yellow, firmer than Durado; clingstone. In central San Joaquin Valley, ripens 10 days after Durado, about 8 to 13 June. Tree: vigorous; upright.

Westerner.- Orig. in Fresno, Calif., by John M. Garabedian. Open-pollinated seedling of unknown origin. Plant patent 5609, 24 Dec. 1985. Fruit: ovate to globular; large, $66 \mathrm{~mm}$; skin dark red; flesh light creamy-white, becoming full red when ripe; stone semi-free. In central San Joaquin Valley, ripens with Laroda, about 15 July. Blossom: medium small, white; anthers yellow. Tree: vigorous; uprightspreading.

Wuhl.- Orig. in Fresno, Calif., by Richard Peters and Eric Wuhl. Plant patent 5585, 3 Dec. 1985. Fruit: ovate; large size, 60 to $65 \mathrm{~mm}$; skin purple; flesh red, little or no bitterness; stone semi-free, not prone to splitting like Black Beaut. In central San Joaquin Valley, ripens 3 days before Santa Rosa, about 15 June. Blossom: small, white. Tree: upright; productive; self-infertile. 


\section{PLUM ROOTSTOCKS}

J.N. Cummins

New York State Agricultural Experiment Station, Geneva

Maridon.- A tetraploid Marianna type orig. in Republic of South Africa from open-pollinated Marianna seeds planted by N. Hurter and M.J. van Tonder, FFTRI, in the 1960s. Tested as no. 8-6. Released in 1990 by J.D. Stadler, G.F.A. Lotze, and J.H. Acker. Compatible with all Japanese plums grown in South Africa. No incompatibility problems have been observed with the several $P$. domestica varieties tested. Incompatible under peaches. Apricots on Maridon break at the graft union. Size of plum trees grafted on Maridon is similar to or slightly smaller than those on Marianna. Precocity and productivity are similar to Marianna. Plum varieties grafted on Maridon appear to be much less susceptible to bacterial canker than those on Marianna. Maridon is propagated commercially by hardwood cuttings; rooting success is similar to that of Marianna.

\section{PLUMCOTS}

D.W. Ramming

U.S. Department of Agriculture Horticultural Crops Research Laboratory, Fresno, Calif.

Red Velvet.- Orig. in Le Grand, Calif., by Norman and Glen Bradford. Unknown plum by unknown apricot. Plant patent 7011, 5 Sept. 1989. Fruit: oblong, compressed transversely; medium size, 44 $\mathrm{mm}$; skin dark purplish-red, pubescent; flesh brilliant yellow, medium firm, flavor acidic unless very ripe, juicy; clingstone. In central California, ripens $\approx 5$ days before Red Beaut. Blossom: medium, white; blooms early; pollinated by Castlebrite apricot. Tree: vigorous; spreading; light productivity; self-unfruitful.

Royal Velvet.- Orig. in Le Grand, Calif., by Norman and Glen Bradford. Unknown plum by unknown apricot. Plant patent 7431, 29 Jan. 1991. Fruit: globose; medium size, $53 \mathrm{~mm}$; skin dark purplish-red, pubescent; flesh light orange-yellow, very firm; sweet and acidic even if under-ripe; juicy; clingstone. In central California, ripens about with Red Beaut. Blossom: medium, white; blooms early; pollinated by Castlebrite and other apricots. Tree: vigorous; upright; uncertain productivity; self-unfruitful.

\section{PUMMELO}

F.G. Gmitter, Jr., and K.M. Crosby

Citrus Research and Education Center, Lake Alfred, Fla.

US 145.- Orig. in 1947 as a seedling of Citrus grandis 'Thong Dee'; selected in 1981 by H.C. Barrett, U.S. Dept. of Agriculture, Orlando, Fla. Fruit: large size, $100 \mathrm{~mm}, 1300 \mathrm{~g}$; globose; rind yellow, smooth, $12 \mathrm{~mm}$ thick; flesh light yellow, moderately firm and juicy; soluble solids $12 \%$ to $15 \%$; acids $1.05 \%$ to $1.13 \%$; midseason. Tree: some cold tolerance; recovers well from freeze damage.

\section{RASPBERRY}

\section{Hugh Dauheny \\ Pacific Agriculture Research Centre, Vancouver, B.C.}

Autumn Britten.- An early ripening, primocane-fruiting raspberry released for eastern Canada. Orig. in East Malling, Kent, U.K., by V.H. Knight, E. Keep, and J.H. Parker, Horticulture Research International. Sibling of Autumn Bliss, with complex derivation involving several red raspberry varieties and Rubus arcticus, $R$. strigosus, and R. occidentulis; tested as EM 3676/6; introd. in 1995. Plant variety rights held by Ontario Berry Growers Assn. Fruit: large; medium to dark red; firm; at times more uniform than Autumn Bliss; usually ripens a few days after Autumn Bliss; can be difficult to harvest in British Columbia but not in Ontario. Plant: yields similar to or slightly higher than Autumn Bliss: canes not as erect as Autumn Bliss; some spines. Susceptible to natural infection from raspberry bushy dwarf virus; gene $A$, gives resistance to the four known strains of the
European aphid vector of the raspberry mosaic virus complex.

Autumn Cascade.- An early ripening, spineless primocane-fruiting raspberry that is easy to harvest. Orig. in East Mailing, Kent, U.K.. by V.H. Knight, E. Keep, and J.H. Parker, Horticulture Research International. Sibling of Autumn Cygnet with complex derivation involving several red raspberry varieties and Rubus odoratus, $R$. arcticus, $R$. strigosus, and $R$. occidentalis; tested as EM 4395/65; introd. in 1994. Plant variety rights held jointly by a United Kingdom nursery and Horticulture Research International. Fruit: medium to large; dark red; firm; compared to Autumn Bliss, ripens 1 week later in Kent but a few days earlier in British Columbia; good flavor. Plant: yields less than Autumn Bliss; spineless. Susceptible to Phytophthoraincited root rot in greenhouse screening test; gene $A_{10}$ gives resistance to the four known strains of the European aphid vector of the raspberry mosaic virus complex.

Autumn Cygnet.- A spineless. primocane-fruiting raspberry adapted to Tasmania, Australia. Orig. in East Mailing, Kent, U.K., by V.H. Knight, E. Keep. and J.H. Parker, Horticulture Research International. Sibling of Autumn Cascade with complex derivation involving several red raspberry varieties and Rubus odoratas, $R$. arcticus, $R$. strigosus, and R. occidentalis: tested as Em 4395/75; introd. in 1994. Plant variety right held by Tasmanian Berry Gardens Pty., Battery Point. Fruit: medium size: glossy, medium-red color. lighter than Autumn Bliss; fairly soft, lacks good coherence; uneven shape; easier to harvest than either Autumn Bliss or Autumn Britten; ripens after Autumn Bliss and before Heritage in Australia but usually before Autumn Bliss in British Columbia; good flavor. Plant: good yield in Australia; canes nearly self-supporting; spineless. Gene $A_{10}$ gives resistance to the four known strains of the European aphid vector of the raspberry mosaic virus complex.

Bogong.- A high-yielding, primocane-fruiting raspberry with large fruit of excellent quality. Orig. in Toolangi, Australia, by G. McGregor, Inst. for Horticultural Development, Victoria. Comox x Autumn Bliss; cross made in 1985; tested as A85-24-A7; introd. in 1994. Fruit: large; glossy, medium red: firmness similar to Heritage: uniform drupelets; easy to harvest; season similar to Heritage; fairly intense aromatic flavor. Plant: high-yielding; canes more branched than Heritage; basal spines.

Clutha.- A high-yielding raspberry with easily harvested fruit adapted to medium-low chill conditions in New Zealand. Orig. in Vancouver, B.C., by H.A. Daubeny, Agriculture and Agri-Food Canada, Pacific Agr. Res. Centre. Meeker x Skeena: cross made in 1974; selected in 1977; tested as BC 74-11-41; introd. into New Zealand in 1983 and released there in 1991 by H. Hall, Riwaka Res. Centre. Fruit: smaller than Willamette and Marcy; moderately glossy, medium-dark red; mid- to late season, ripening 3 to 4 days later and peaking 10 days later than Marcy; processing. Plant: yield higher than Marcy and Skeena; moderate numbers of medium-strong, semiupright canes; floricanea dark brown with few spines; strongly attached laterals with high fruit numbers; good budbreak in New Zealand. Moderately susceptible to cane spot in New Zealand: susceptible to cane Botrytis in British Columbia; susceptible to natural infection by raspberry bushy dwarf virus in British Columbia, but slow to become infected in New Zealand, where it is under high infection pressure; resistant to the common strain of the North American aphid vector of the raspberry mosaic virus complex.

Double Delight.-A winter-hardy, relatively early ripening, primocane-fruiting raspberry with an attractive appearance. Orig. in Morden, Manitoba, by C. Davidson, Agriculture and Agri-Food Canada, Morden Res. Centre. (Fall Red x primocane-fruiting type derived from Rubus strigosus from Cheyenne, Wyo.) x (Fall Red x Boyne); cross made in 1968; selected in 1978; tested as MRS\#8114; introd. in 1993. Propagated under royalty agreement by Prairie Plant Systems, Saskatoon. Saskatchewan, and by Jefferson Nurseries, Portage la Prairie, Manitoba. Fruit: small; tnedium bright red; attractive; firm with good drupelet coherence; conic with conspicuous round point: tendency for twin fruit to form from the same flower; flavor comparable to Red River. Ripens before Heritage or Redwing, 10 days after Red River. Plant: yield similar to Red River; canes relatively long and thick; height 1 to $1.5 \mathrm{~m}$; spines green, turning to red in fall; may need trellis; moderate primocane production; hardy to at least U.S. Dept. of Agriculture zone 3. 
Glen Ample.- A high-yielding raspberry with fruit especially well-adapted to fresh market in southern Britain. Orig. in Invergowrie, Scotland, by R.J. NcNicol and D.L. Jennings, Scottish Crop Res. Inst. Sibling of Glen Rosa; complex parentage includes Glen Prosen and Meeker; cross made in 1978; tested as SCRI 7815B8; introd. in 1994. Worldwide marketing rights held by NSA Plants, West Malling, Kent, U.K. Fruit: medium to large size; bright red; round-conic shape; firm with slight tendency to break at the collar in wet and cool conditions; easily removed from receptacle; adapted to machine harvest; midseason ripening; excellent flavor; fresh market and processing. Plant: spinefree; upright, vigorous canes with long, upright laterals. Gene $A_{l}$ gives resistance to two strains of the European aphid vector of the raspberry mosaic virus complex.

Glen Magna.- A very high-yielding, late-ripening raspberry. Orig. in Invergowrie, Scotland, by R.J. McNicol and D.L. Jennings, Scottish Crop Res. Inst. Meeker x SCRI 77 19B11; cross made in 1980; tested as SCRI 8032A3; introd. in 1994. Worldwide marketing rights held by NSA Plants, West Malling. Kent, U.K. Fruit: very large; deep red color; long conic shape; medium firm; excellent uniform appearance; removal from receptacle may not be sufficiently easy in some environments for machine harvest; excellent flavor with similarities to Meeker and Glen Moy; fresh market and processing, especially freezing. Plant: upright, vigorous canes with few spines. Gene $A$, gives resistance to two strains of the European aphid vector of the raspberry mosaic virus complex; gene $\mathrm{Bu}$ gives resistance to raspberry bushy dwarf virus.

Glen Rosa.- A raspberry with easily harvested fruit, well adapted to the cool growing conditions of Scotland. Orig. in Invergowrie, Scotland, by R.J. McNicol and D.L. Jennings, Scottish Crop Res. Inst. Sibling of Glen Ample; complex parentage includes Glen Prosen and Meeker; cross made in 1978; tested as SCRI 7815A12; introd in 1994. Worldwide marketing rights held by NSA Plants, West Mailing, Kent, U.K. Fruit: medium size; bright medium-red color: firm with good collar adhesion; easily removed from receptacle; adapted to machine harvest; midseason ripening; fairly good flavor; for processing, less well adapted to fresh market. Plant: production moderate; spine-free, relatively upright canes with medium vigor. Gene $H$ gives resistance to spur blight and cane Botrytis: gene $A_{10}$ gives resistance to the four known strains of the European aphid vector of the raspberry mosaic virus complex; gene $B u$ gives resistance to raspberry bushy dwarf virus.

Glen Shee.- A large-fruited raspberry probably best suited to home gardens and pick-your-own in Britain. Orig. in Invergowrie, Scotland, by R.J. McNicol and D.L. Jennings, Scottish Crop Res. Inst. Complex parentage with no named cultivar in its pedigree for four generations; cross made in 1980; tested as SCRI 8044C9; introd. in 1994. Worldwide marketing rights held by NSA Plants, West Mailing, Kent, U.K. Fruit: slightly pale; firm; fleshy; slightly weak skin prone to wind rub; not adapted to machine harvest; moderate flavor. Plant: moderate yield; spine-free; canes relatively upright, strong, vigorous. Susceptible to midge blight; gene $A$, gives resistance to two strains of the European aphid vector of the raspberry mosaic virus complex; susceptible to natural infection from raspberry bushy dwarf virus.

Joan Squire.- A high-yielding, primocane-fruiting raspberry with excellent fruit quality. Orig. in Kent, U.K., by D.L. Jennings, Medway Fruits. Selected from parents of complex origin; tested as 89111E2; introd. in 1995. Worldwide marketing rights held by NSA Plants, West Mailing, Kent. Fruit: size similar to Autumn Bliss, larger than Heritage: firm; cohesive; skin strength nearly as good as Heritage; attractive medium red with some gloss, no tendency to develop blue tinge; in southern England. ripens 2 weeks later than Autumn Bliss, 2 weeks before Heritage; good shelf life; excellent flavor. Plant; more productive that either Autumn Bliss or Heritage; numerous vigorous, spinefree canes; spreading habit; canes need support as fruit ripens.

Qualicum.- A high-yielding, midseason raspberry producing large, firm fruit with a good shelf life. Orig. in Vancouver, B.C., Canada, by H.A. Daubeny, Agriculture and Agri-Food Canada, Pacific Agr. Res. Centre. Glen Moy x Chilliwack; cross made in 1983; selected in 1986; tested as BC 83-16-50; introd in 1995. Propagated under a royalty agreement by Sieglin Ent., Abbotsford, B.C. Fruit: conic: medium red, slightly less glossy than Chilliwack; easily removed from the receptacle; can be machine-harvested; relatively high soluble solids; pleasant fresh flavor; some resistance to pre- and postharvest fruit rots; fresh market and processing, including individual quick freeze. Plant: vigorous, upright habit; primocanes fairly numerous, light rosy-red color with dark purple spines mostly at base; floricanes light brown with gray overlay and basal cracking; long, strongly attached laterals tend to droop; fruit spaced well apart along laterals; winter hardiness in the Pacific Northwest similar to Meeker. less than Chilliwack. Some resistance to spur blight; resistant to powdery mildew; susceptible to cane Botrytis and cane spot; susceptible to Phytophthora-incited root rot in greenhouse screening test; may have resistance to natural infection by raspberry bushy dwarf virus; resistant to the common strain of the North American aphid vector of the raspberry mosaic virus complex.

Rakaia.- A midseason raspberry adapted to cooler conditions in New Zealand. Orig. in Lincoln, New Zealand. by I. K. Lewis, DSIR Crop Research Division. Marcy x Fairview: cross made in 1979; tested as E6; introd in 1986. Fruit: larger than Marcy; dark red; conic ovate shape; easy to harvest; ripens 12 to 16 days after Marcy. Plant: yields less than Marcy or Skeena under warmer conditions but higher than either under cooler conditions; small numbers of medium-strength, semi-upright canes; floricanes dark brown with prominent basal spines of moderate length; strongly attached laterals bear 20 to 30 fruit; very susceptible to raspberry bud moth. May have resistance to natural infection by raspberry bushy dwarf virus.

Rossana.- A primocane-fruiting raspberry with an excellent flavor. Orig. at Univ. of Torino, Italy, by R. Paglietti. Open-pollinated Malling Promise; tested as MP 45. Fruit: medium size, larger than Heritage; bright red; conic: not as firm as Heritage; I week later than Heritage in Italy, 3 to 4 weeks after Heritage in Minnesota; some resistance to rot; local and distant fresh markets. Plant: productive: fruit spaced well apart along laterals and well-exposed; overwintered canes not hardy in Minnesota; hardy to U.S. Dept. of Agriculture zone 4.

Selwyn.- An early ripening raspberry adapted to New Zealand. Orig. in Nelson, New Zealand, by H. Hall. Riwaka Res. Center. Marcy x Mailing Delight; cross made in 1979 by H.A. Daubeny, Agriculture and Agri-Food Canada, Pacific Agr. Res. Centre, Vancouver, B.C.; seedlings grown in 1984 and selection made in Lincoln, New Zealand. in 1987; tested as F36; introd. in 1992. Fruit: medium size; medium red; relatively soft: conic ovate shape: relatively difficult to harvest; season similar to Marcy. Plant: slow to establish with small to medium number of relatively upright canes; floricanes medium red to brown with bloom and basal spines: strongly attached, medium-length laterals with 10 to 20 fruits each. May have resistance to natural infection by raspberry bushy dwarf virus.

Souris.- A hardy, floricane-fruiting raspberry with better flavor than Boyne. Orig. in Morden, Manitoba. by C. Davidson. Agriculture and Agri-Food Canada, Morden Res. Center. Asker x Boyne: cross made in mid- 1960s; tested as MRS\#1 x 8: introd. in 1993. Propagated under a royalty agreement by Jefferies Nurseries, Portage la Prairie, Manitoba. Fruit: small; hemispherical shape; appearance similar to Boyne but with larger drupelets; season similar to Boyne; fresh market. Plant: yield greater than or equal to Boyne: canes have fewer spines than Boyne; self-supporting under test conditions: more primocanes produced than Boyne. Hardy to U.S. Dept. of Agriculture zone 2.

Waiau.- A high-yielding raspberry adapted to medium-low chill New Zealand conditions. Orig. in Nelson. New Zealand, by H. Hall, Riwaka Res. Center. Fairview x Marcy: cross made in 1979 by H.A. Daubeny, Agriculture and Agri-Food Canada, Pacific Agr. Res. Centre, Vancouver, B.C.; seedlings grown in 1984 and selection made in Lincoln, New Zealand, in 1987; tested as R61 ; introd. in 1990. Fruit: large; light-medium red and moderately glossy; firm; moderately difficult to harvest; mid- to late season, ripening 6 to 8 days after Marcy. Plant: large numbers of semi-upright canes that arch into row; floricanes light brown with gray bloom and basal spines: moderate budbreak; medium-length, strongly attached laterals with 30 to40 fruit each; leafy habit hides some fruit, Susceptible to root rot and to natural infection by raspberry bushy dwarf virus. 


\section{STRAWBERRIES}

\section{Hugh Daubeny \\ Pacific Agriculture Research Centre, Vancouver, B.C.}

Belle Rouge.- A high-yielding strawberry adapted to forcing under plastic and for open culture in cooler regions of Japan. Orig. at the Morioka Branch, National Res. Inst. of Vegetables. Ornamental Plants and Tea, Japan; introd. in 1989. Fruit: large; glossy red; conic; mid- to late season; firm flesh and skin; good shelf life; adapted to long-distance shipping. Plant: productive.

Cortina.- A high-yielding, fresh-market strawberry producing firm fruit. Orig. near Comacchio (Ferrara), Italy, by M. Leis, D. Musacchi, A. Martinelli, Consorzio Italiano Vivaisti. Addie x Parajo; cross made in 1984; introd. in 1992. Fruit: medium to large size; intense bright red external and red to orange internal color; some hollowness; heart shape with pointed apex; large calyx easily removed; achenes beneath surface; season similar to Addie; good flavor with medium sweetness and considerable acidity. Plant: medium vigor; moderate runner production; moderately upright habit; flowers early and at level of leaf canopy.

Curtuno.- A fresh-market strawberry producing uniform-appearing fruit, adapted to protected culture. Orig. in Tudela-Narvarra, Spain, by J.M.A. Lopez. Parents were seedlings obtained from open pollination among 32 varieties; tested as 89-33-018; introd. in 1992. Assignee, Plantas de Navarra, S.A. Valtierra, Spain. Plant patent 8632 Fruit: somewhat similar to Chandler; large primaries; firm; orangered, glossy external; medium-red internal color; nearly conic; achenes below surface; reflexed calyx: medium sweet and low acid. Plant: medium vigor; erect inflorescence above foliage; medium chilling requirement.

Delmarvel.- A disease-resistant strawberry with excellent fruit quality; adapted tomid-Atlantic andadjacent states. Earliglow x Atlas; cross made by A.D. Draper in 1977; selected in 1979 by G.J. Galletta and A.D. Draper; tested as MDUS 4923; introd. in 1994 by U.S. Dept. of Agriculture, Beltsville, Md.; Ohio Agr. Res. and Development Center, Ohio State Univ.; and New Jersey Agr. Expt. Sta., Rutgers Univ. Fruit: large; firm; symmetrical; good color; early midseason ripening; some rot resistance; withstands handling, adapted to shipping; good flavor with outstanding aroma. Plant: productive in matted rows or hill culture in either light or heavy soils; vigorous; abundant runners. Resistant to five races of red stele root rot causal organism; resistant to most leaf and stem diseases.

Ever Berry.- An ever-bearing strawberry adapted to cooler regions of Japan. Orig. at the Morioka Branch of the National Res. Inst. of Vegetables, Ornamental Plants and Tea, Japan; introd. in 1992. Fruit: medium size; relatively soft; glossy red-orange; conic; uniform. Plant: high-yielding; intermediate vigor and runner production: high chilling requirement.

Gardena.- A high-yielding, fresh-market strawberry. Orig. near Comacchio (Ferrara), Italy, by M. Leis, D. Musacchi. A. Martinelli, Consorzio Italiano Vivaisti. Addie x Parajo; cross made in 1984; introd. in 1992. Fruit: medium to large size; deep red external and red to orange internal color: firm; some hollowness; mostly uniform heart shape with pointed apex; large calyx that is difficult to remove; achenes beneath surface. Ripens 2 days before Addie; medium-sweet flavor with considerable acidity. Plant: medium vigor; sparse runner production; upright habit; flowers at leaf canopy level.

Hinomine.- A high-yielding, early ripening strawberry adapted to forcing under plastic in both warm and cool regions of Japan. Orig. at the Kurume Branch of the National Res. Inst. of Vegetables, Ornamental Plants and Tea, Japan; introd. in 1989. Fruit: large; firm; glossy deep scarlet. Plant: productive; establishes quickly. Resistant to powdery mildew and fusarium wilt,

Lambada.- A high-quality, early ripening strawberry adapted in The Netherlands to both forcing under plastic tunnels and outdoor cultivation. Orig. at CPRO-DLO in Wageningen, Netherlands. (Sivetta x Holiday) x (Karina x Primella); introd. in 1992. Fruit: large; bright red; relatively firm, does not bruise readily; conic with exposed neck; uniform; reflexed calyx. Ripens early, 2 or 3 days before Gorella; considerable rot resistance; excellent flavor. Plant: moderate produc- tivity; vigorous; stiff petioles; long scapes. Probably resistant to powdery mildew and verticillium wilt; some resistance to red stele and crown rot; moderately susceptible to leaf spot.

Mohawk.- An early ripening, fresh-market strawberry adapted to southwestern Canada and the northeastern United States. Orig. in Beltsville, Md. MDUS 4587 x Earliglow; cross made in 1979 by G.J. Galletta; selected in 1981 ; tested as MDUS 5122; introd. in 1994 by G.J. Galletta, J.L. Maas, J.M. Enns, and A.D. Draper, U.S. Dept. of Agriculture, Beltsville; A. Dale, Hort. Res. Inst. of Ontario; and H.J. Swartz, Dept. of Horticulture, Univ. of Maryland. Fruit: medium large: irregular short conic; glossy, deep scarlet exterior, pink interior; flesh juicy but firm texture, skin firm; achenes yellow and recessed; calyx clasping to partially reflexed. Ripens 2 or 3 days before Earliglow in Maryland and before Veestar in Ontario; good shelf life; flavor mild, sweet, and subacidic. Plant: vigorous; medium to tall; dense crowns with many leaves; petioles erect and thick; abundant runners; yields similar to Earliglow in Maryland and less than Veestar in Ontario. Resistant or tolerant to powdery mildew, leaf scorch, leaf blight. Resistant to at least six races of the red stele causal organism.

Nanaimo.- A strawberry producing fruit with high soluble solids, suited to both fresh and processing markets. Orig. in Vancouver, B.C., Canada, by H.A. Daubeny, Agriculture and Agri-Food Canada, Pacific Agr. Res. Centre. Totem x Korona. Cross made in 1986; selected in 1988; tested as BC 86-33-2; introd. in 1995. Fruit: medium to large; bright medium-red external and internal color; medium firm; mostly wedge shape; calyx easily removed; achenes slightly raised; midseason ripening; reactions to pre- and postharvest rot similar to Totem; excellent fresh flavor. Plant: productive; good vigor; relatively upright habit; adequate runner production; as winter hardy as Totem. Slightly more susceptible to powdery mildew than Totem; tolerant to the aphidborne virus complex in the Pacific Northwest; reaction to red stele unknown.

Northeaster.- An early ripening, red stele-resistant strawberry adapted to the northeastern United States. Orig. in Beltsville, Md. MDUS 4380 x Holiday; cross made by D.H. Scott in 1974; selected in 1976 by A.D. Draper and P. Rosati; tested as MDUS 4787; introd. in 1994 by U.S. Dept. of Agriculture, Beltsville, and New Jersey Agr. Expt. Sta., Rutgers Univ. Fruit: large; firm; ripening season similar to Earliglow; recommended for fresh market and processed frozen; strong flavor and aroma, similar to Holiday. Plant: yields on sandy soil similar to Earliglow, on heavier soils yields more than Earliglow; less vigorous than Earliglow on lighter soils and more vigorous on heavier soils. Resistant to five races of red stele causal organism; susceptible to powdery mildew.

Nyoho.- A high-yielding strawberry adapted to forcing under plastic in cool regions of Japan. Orig. at the Tochigi Agr. Expt. Sta., Japan, by F. Honda. Kei 210 x Reiko; cross made in 1979; introd. in 1984. Fruit: relatively small; glossy scarlet color: conic; aromatic. Plant: vigorous; relatively low chilling requirement. Relatively susceptible to powdery mildew; susceptible to fusarium wilt and anthracnose.

Redlands Horizon.- A fresh-market strawberry for the coastal southeastern region of Queensland, Australia. Orig. Queensland Dept. of Primary Industries Hort. Centre, Redlands Res. Sta., by M. Herrington, P. Brown, and S. Prytz. Earlisweet x Parajo; cross made in 1985; tested as 24/86: introd. in 1993. Fruit: large size in early season to medium later; glossy red external and paler red internal color; conic to globose shape; early to midseason ripening; pleasant, slightly acidic flavor. Plant: small; flat, open habit allows good spray penetration; fruit well-displayed; sparse runner production. Tolerance to leaf blight similar to Earlisweet.

Rhapsody.- A high-yielding, mid-late-season strawberry adapted to Northern England and Scotland. Orig. in Invergowrie, Scotland, by R.J. McNicol, Scottish Hort. Res. Inst. SCRI 61G51 (Talisman x Cambridge Vigor) x Cambridge Favorite; cross made by H.J. Gooding at Auchincruive in 1969; tested as SCRI 69EW30; introd. in 1988. Fruit: medium to large size; firm; glossy red exterior and solid red interior color, tip tends to remain white; conic; calyx removal moderately difficult, tends to plug; juicy; good flavor; late fresh market. Plant: erect habit with medium to strong vigor; moderate runner 